\title{
The impact of knowledge governance mechanisms on supply chain performance: Empirical evidence from the agri-food industry
}

Guoqing Zhao ${ }^{\mathrm{a}}$, Jorge Hernandez Hormazabal ${ }^{\mathrm{b}}$, Sebastian Elgueta ${ }^{\mathrm{c}, \mathrm{d}}$, Juan Pablo Manzur,

Shaofeng Liu ${ }^{\mathrm{a}}$, Huilan Chen ${ }^{\mathrm{a}}$, Carmen Lopez ${ }^{\mathrm{e}}$, Dulekha Kasturiratne ${ }^{\mathrm{a}}$, Xiaoning Chen ${ }^{\mathrm{a}}$

a \{guoqing.zhao; shaofeng.liu; huilan.chen; dulekha.kasturiratne;

$$
\begin{gathered}
\text { xiaoning.chen\}@ plymouth.ac.uk } \\
\text { bJ.E.Hernandez@liverpool.ac.uk } \\
\text { c,d } \text { sebastian.elgueta@inia.cl } \\
\text { cjpmanzur@uc.cl } \\
\text { eC.Lopez@ soton.ac.uk }
\end{gathered}
$$

aUniversity of Plymouth, Drake Circus, Plymouth, PL4 8AA, United Kingdom

bUniversity of Liverpool, Liverpool, L69 3BX, United Kingdom

${ }^{c}$ Laboratory of Pesticide Residue and Environment, Instituto de Investigaciones

Agropecuarias, INIA La Platina, 11610, Chile

${ }^{\mathrm{d} N u ́ c l e o ~ d e ~ I n v e s t i g a c i o n e s ~ A p l i c a d a s ~ e n ~ C i e n c i a s ~ V e t e r i n a r i a s ~ y ~ A g r o n o ́ m i c a s, ~ U n i v e r s i d a d ~}$ de las Américas, Sede Providencia, Santiago, Chile

e University of Southampton, Highfield, Southampton, SO17 1BJ, United Kingdom

\section{Corresponding author:}

Guoqing Zhao

University of Plymouth, UK

guoqing.zhao@plymouth.ac.uk 
Abstract The agri-food supply chain (AFSC) is an extremely complex structure that comprises a series of events from farm-to-fork. Additionally, there is a wide range of information and material flows required to be managed, which are seen as the knowledge flow in the AFSCs. It is expected that the use of knowledge governance mechanisms (KGMs) will help in enhancing AFSC performance. To examine the impact of KGMs on AFSC performance, a mixed methods research design was applied. First, semi-structured interviews were conducted to collect data. Then, themes were generated through thematic analysis. Afterwards, relationships between KGMs and AFSC performance were built by using total interpretive structural modelling (TISM). Finally, questionnaire-based structured interviews were undertaken to evaluate the empirical and theoretical findings further. The research results indicate that trust-, reciprocity-, market-, and contract-based KGMs have positive effects on product quality, efficiency, flexibility, responsiveness, and process quality of AFSC. Furthermore, market-based KGM, located in the lowest level in the TISM hierarchy, should be given additional focus due to its role as a key force driving the higher level of AFSC performance and other KGMs. The findings provide AFSC practitioners with useful guidance on how the relationships between KGMs and AFSC performance should be managed to improve the performance of AFSC.

Keywords: Knowledge governance mechanisms, agri-food supply chain, total interpretive structural modelling, supply chain performance 


\section{Introduction}

Globalisation, along with rapid urbanisation, diet diversification, and evolving regulatory and legislative interventions, drive the increase of better quality, rich nutrition, and low pesticide usage in agri-food products (Tsolakis et al. 2014). Many initiatives such as genetically modified seeds, traceability in the farms, hydroponics systems, and blockchain technology have been introduced to increase agri-food products' quality, nutrition, and safety, but these are still far from enough because agri-food products have many unique characteristics (e.g., shelf life constraints, perishability, long production throughput time, and seasonality in production) that make them extremely difficult to manage (Zhao et al. 2019). In fact, as established by Hernandez and Kacprzyk (2020), the way to address the agri-food supply chains (AFSCs) challenges is by considering a combined range of disciplines, which leads to a proper agri-food analysis and understanding. In their novel work, they analyse major agri-food challenges in Europe and South America, specifically to understand how risk and uncertainties can be managed by means of validated data and results from agri-food systems analysis. In addition, AFSC challenges are addressed from the real-life industry perspective. To cope with these challenges, agri-food companies and academia have recognised and started to re-consider these challenges from the whole AFSC perspective, and have also tried to apply a series of new measures in AFSC such as "lean" principle and "circular economy" to improve its performance (Samuel et al. 2011; Herbert et al. 2015; Jasti and Kodali. 2015; Puche et al. 2016; Angelis et al. 2018). Scholarship has suggested that these measures have the potential to increase AFSC practitioners' output, cooperation and networks, but companies are failing to apply the techniques and tools as the majority of companies in the food sector are SMEs (Vlachos. 2015; Mangla et al. 2018a). An AFSC comprises a series of events in a farm-to-fork sequence, including farming, processing, testing, packaging, warehousing, transportation, distribution, and marketing (Iakovou et al. 2010). Besides, a variety of financial, information, technology, 
and material flows are crossing both downstream and upstream of AFSC (Mentzer et al. 2001); this is also supported by Hernandez et al. (2008), who established a holistic framework to support supply chain complexity analysis by considering products, information and decision flows. In such a complex system, management of the processes of adoption, creation, storage, transfer and application of knowledge appears to be the necessary response to the new challenges posed by supply chain globalisation and sustainability issues (Cerchione and Esposito, 2016).

Based on the knowledge-based view (KBV), a supply chain's ability to create and transfer knowledge can yield competitive differentiation (Blome et al. 2014). In the context of AFSC, organisations always require access to partners' knowledge and new skills (e.g., market preferences, pest and disease controls, seed cultivation, waste reduction, and greenhouse technologies), which they consider necessary or useful for their internal decision-making, operating performance, and the overall supply chain performance (Chen et al. 2019). In recent years, there has been an increasing interest in identifying factors, barriers, appropriate tools and practices related to adoption and facilitation of knowledge management (KM) in supply chains (Huang and Lin, 2010; Dooley et al. 2013; He et al. 2013; Lim et al. 2017). Despite this, the research on the relationship between KM and supply chain performance is still in its infancy and needs much closer attention (Liu et al. 2012; Abid and Ali, 2014; Aboelmaged, 2014; Handfield et al. 2015; Batista et al. 2019). The expertise and knowledge of how to use knowledge governance mechanisms (KGMs) to capture, share, create and use knowledge to improve supply chain performance are still poorly developed (Foss et al. 2010). KGMs are the life-blood of supply chains, and have been considered as a major enabler for offering competitive advantage as well as continued growth and prosperity for supply chain partners (Wadhwa and Saxena, 2005). They have the ability to improve the economic, financial, market, technical, and organisational performances of AFSCs, and appear to be one of the best choices 
for AFSC managers (Marra et al. 2012; Cerchione and Esposito, 2016). Although there is a vast amount of literature investigating KGMs from a number of perspectives - knowledge creation, knowledge capture, knowledge organisation, knowledge storage, knowledge dissemination, and knowledge application - most studies have focused on the intraorganisational context rather than the inter-organisational context (Samuel et al. 2011). Additionally, the role of KGMs still seems to be neglected in the field of SCM (Marra et al. 2012; Cerchione and Esposito. 2016). In particular, scant attention has been given to investigate the relationship between KGMs and AFSC performance (Sangari et al. 2015).

The aim of this paper is to address this gap by investigating the impact of KGMs on AFSC performance. Accordingly, three research questions are formulated:

- $\quad$ RQ1: What are the key elements required for building different KGMs and measuring AFSC performance?

- $\quad$ RQ2: How can the AFSC performance be improved by implementing different KGMs?

- RQ3: What is the applicability of the identified relationship between KGMs and AFSC performance for practical use?

By answering these questions, this paper makes three contributions to the knowledge management (KM) and SCM field. First, through analysing different elements of KGMs in the context of AFSC, this research contributes to the body of $\mathrm{KM}$ by providing a holistic understanding of which elements are effective in forming different KGMs. Second, different performance indicators used for AFSCs are identified and evaluated, which provides a comprehensive performance measurement system (PMS) to AFSC practitioners to evaluate the performance of AFSC. However, measuring performance of AFSC has proven extremely difficult because of multiple inputs and outputs in the system (Aramyan et al. 2007). Third, the impact of KGMs on the AFSC performance is explored in this paper. The findings provide 
AFSC practitioners with a visual framework to illustrate how different KGMs can influence the performance of AFSC. Thus, AFSC practitioners can choose the most effective approaches based on the real-life content to increase their performance.

The rest of the paper is structured as follows. Section two reviews existing literature on KGMs and AFSC performance, respectively, while the research methodology is discussed in section three. Then, the empirical data collection is presented in section four, followed by data analysis, findings, and evaluation in section five. Further, discussion and implications are considered in section six. Finally, conclusions and future research directions are drawn in section seven.

\section{Literature review}

This section reviews existing literature on KGMs and AFSC performance. Based on the literature review results, research gaps are proposed, and a holistic framework is created and validated by stakeholders, which is to be used to support key agri-food decision-making processes in the context of agri-food KM.

\subsection{Knowledge governance mechanisms}

Knowledge governance is a relatively new concept, which refers to the application of formal or informal rules that coordinate, guide and regulate knowledge processes, including knowledge creation, knowledge sharing, as well as access to and use of knowledge (van Kerkhoff, 2014; Clark et al. 2016). It includes four aspects - governance environment, governance mechanisms, governance implementation, and governance goal (Choi et al. 2005). Governance mechanisms are identified critically because they coordinate the behaviour of organisational members, facilitate knowledge communications, and decrease conflicts and misunderstandings during the KM process (Yang, 2011; Fang et al. 2013). It is increasingly accepted among academics and practitioners that KGMs have become a useful organisational 
strategy for value creation and sustainable competitive advantage (Lyles and Salk, 2007). KGMs have been divided into two categories; these are formal KGMs and informal KGMs (Huang et al. 2013). Many scholars (e.g., Cao and Xiang. 2012; Wang et al. 2018) have suggested that formal KGMs represent an effective way to motivate employees to expend effort on searching, creating, sharing and transferring knowledge. Performance evolutions, incentives and other reward systems, promotions, training, bonuses, and performance-based pay all can be seen as measures of formal KGMs (Wang and Noe. 2010). Informal KGMs are primary means for establishing interpersonal relationships, which can help people to share knowledge (Yamao et al. 2009). Social norms, teamwork, and trust can be seen as measures of informal KGMs (Quigley et al. 2007).

Besides categorising KGMs into formal and informal, KGMs also can be divided into four groups, which are trust-based, market-based, reciprocity-based and contract-based KGMs (Fang et al. 2013). A trust-based KGM is a way of fostering trust between partners for facilitating knowledge transfer (Nooteboom. 2000). It can be seen as a key factor in forming collaborative inter-organisational relationships, reducing costs and risks involved in collaboration, facilitating supply chain learning, and further increasing overall supply chain performance (Bunduchi, 2013). Key antecedents for building trust such as existing relationship (Smith Ring et al. 1994), third party referrals (Das and Teng, 2001), accurate and open communication (Bstieler, 2006), and geographical proximity (Bonte, 2008), all have proved effective in facilitating inter-organisational knowledge transfer in various supply chains (Rutten et al. 2016). In the market-based KGM, prices afford high-powered incentives that encourage members to explore and exploit knowledge, and then apply the acquired knowledge to their products to further satisfy the market requirements (Nickerson and Zenger, 2004). In these conditions, knowledge is transferred and exchanged at a market price based on the negotiation between supply and demand. This type of KGM is more suitable for acquiring 
tangible aspects of knowledge, such as technology or patents (Millar and Choi, 2010). Polanyi (1957, p. 210) defined reciprocity as "the giving and receiving according to need", which is a key mechanism to maintain the stability of supply chain and exchange relationships. The reciprocity-based $\mathrm{KGM}$ is a way to help build reciprocal relationships between members for facilitating knowledge transfer. Relationships based on reciprocity may promote the transfer/share of distinctive knowledge and resources because stable relationships between involved parties have been built (Inkpen and Tsang, 2005). Finally, the contract-based KGM is a form of control and coordination for building social bonds between partners for facilitating knowledge transfer (Fang et al. 2013). Contracts are always used to specify the roles and obligations of contracting parties through very detailed, explicit, and legally written documents (Vandaele et al. 2007). Besides its coordination function, literature has emphasised the following functions of the contract: (i) safeguarding function for protecting parties against potential opportunism and financial and operational uncertainties (Kern and Willcocks, 2000), (ii) adaption function for adjustments resulting from market changes (Schepker et al. 2014), and (iii) learning function for partner-specific learning and joint improvements (Mayer and Argyres, 2004).

Based on the aforementioned literature review on KGMs, we use trust-based, marketbased, reciprocity-based and contract-based KGMs to identify elements of different KGMs for the following reasons. First, we suggest more specific KGMs are used to facilitate formal and informal interactions between individuals and between groups (Sammarra and Biggiero, 2008). Some researchers categorised KGMs into formal and informal (Huang et al. 2013); however, this is too broad and cannot be used to identify elements of different KGMs. Second, more specific categorisation of KGMs can be used as a guide to help us identify more elements of different KGMs.

\subsection{AFSC performance measurement}


An AFSC consists of different levels - namely, input supplier, farmer, cooperative, food processor, distributor/wholesaler, retailer, and consumer - and it is a complex system responsible for the circulation of agri-food products from the initial stage of production to the final stage of consumption (Zhao et al. 2019). Due to the high complexity of the AFSC's network and the extreme difficulty in monitoring every node in the AFSC, food safety issues (e.g., food contamination and animal disease) are frequently reported and disseminated (Wang et al. 2012). Subsequently, many organisations are forced to focus on improving the overall AFSC performance rather than only focusing on their internal operations (Najmi and Makui, 2012). Therefore, there is no doubt that measuring AFSC performance has received significant attention from academia and the agri-food industry to improve understanding, strengthen the collaboration between AFSC partners, and increase whole AFSC integration (Aramyan et al. 2007; Dey and Cheffi, 2013; Jakhar and Barua, 2014; McAdam et al. 2017; Ukko et al. 2020). In order to be able to assess the performance of supply chains, an adequate PMS is essential. Maestrini et al. (2017, p.301) defined supply chain PMS as a "set of metrics used to quantify the efficiency and effectiveness of supply chain processes and relationships, spanning multiple organisational functions and multiple firms and enabling supply chain orchestration”. It has two broad roles in managing supply chain performance. The first is to ensure that organisations have clear objectives and explicit strategies to achieve objectives. The second is to measure performance against these objectives to provide feedback as to whether or not the goals are being achieved (Martinez et al. 2010). The extant literature provides numerous supply chain PMSs. For example, Gunasekaran et al. (2001) suggested assessing performance from strategic, tactical and operational levels of the supply chain. Hence, supplier, delivery, customer service, inventory and logistics cost are included in their supply chain PMS. Simatupang and Sridharan (2005) proposed a framework that includes five connecting features of collaboration to evaluate supply chain collaborative performance; these are collaborative 
performance systems, information sharing, decision synchronisation, incentive alignment, and integrated supply chain processes. Agarwal et al. (2006) developed a framework for measuring supply chain performance, which included market sensitiveness, process integration, information driver and flexibility. Based on the recent literature review on supply chain PMSs, Maestrini et al. (2017) identified four supply chain PMSs that are frequently cited in the literature, which are supply chain balanced scorecard (BSC) developed by Kaplan and Norton (1992), supply chain operations reference model (SCOR) developed by Supply Chain Council in 1996, resource output flexibility model developed by Beamon (1999), and the process-based supply chain PMS (Lambert and Pohlen, 2001). Most of these PMSs entail financial and nonfinancial as well as quantitative and qualitative metrics. For example, Beamon (1999) proposed three types of performance measures - resources, output and flexibility - as necessary components for supply chain PMS. The SCOR links performance metrics, supply chain processes, best practices, and people into a unified structure, and has been widely applied for supply chain optimisation and evaluation (Sangari et al. 2015). Five supply chain performance attributes are considered in the SCOR model; these are reliability, responsiveness, agility, costs, and assets management. In the BSC model, Kaplan and Norton (1992) categorised performance measures into four groups - finance, customer, internal business process, learning and growth - in which supply chain management (SCM) goals, end-customer benefit, financial benefit and SCM improvement are discussed. Finally, a series of quantitative and qualitative performance measures (e.g., order fulfilment, demand management, demand forecasting) are deployed in the process-based model to assess the efficiency and effectiveness of each supply chain.

The supply chain PMSs may be used for measuring the AFSC performance, but performance metrics should reflect more on the quality aspects of AFSC products (Aramyan et al. 2007). For example, seven performance indicators of food quality including sensory properties, food safety, food nutrition, packaging, production system, production handling and 
transportation, and environmental aspects, were added to the SCOR model when measuring performance of the milk supply chain in Pakistan (Moazzam et al. 2012). Aramyan et al. (2007) suggested efficiency, flexibility, responsiveness, product quality, and process quality can be used for evaluating the performance of the tomato supply chain. However, Dinu (2016) argued that only efficiency needs to be considered in measuring the performance of AFSC because of perishability and short shelf-life of agri-food products. Thus, their model proposes four performance indicators, which are on-time loading, days on stock, days out of stock, and cost saving. Chae (2009) holds a similar view that only a small list of performance indicators is critical for AFSC performance. Hence, four categories of performance indicators (e.g., sales and marketing, production, purchasing, and operation strategy) are used to assess AFSC performance. Considering the above literature review on supply chain PMSs, we propose the use of efficiency, flexibility, responsiveness, product quality, and process quality as measures to assess AFSC performance due to the following reasons. First, agri-food products have special characteristics such as perishability, short-shelf life, easily contaminated and high dependency on climatic conditions, and they require air-conditioned transportation and storage (Zhao et al. 2020). Therefore, performance measures should reflect the quality aspects of the product and process. Second, only a limited number of performance measures are critical for the agri-food company's operation management, customer service and financial viability. Besides, these performance measures should be easily monitored and managed (Chae, 2009). Third, financial and non-financial indicators should be included to measure AFSC performance (McArthur, 1996; Aramyan et al. 2007), as most of the classical supply chain PMSs did.

\subsection{Research gaps and theoretical framework}

Based on the above discussion and some key characteristics of relevant literature summarised in Table 1, three research gaps are identified. 
- First, little research has been conducted to explore the influence of KGMs on AFSC performance. After conducting a comprehensive literature review on supply chain KM, Marra et al. (2012) highlighted a lack of studies measuring the impact of KGM practices on the AFSC performance. Therefore, it is evident that the impact of KGMs on AFSC performance demands more research.

- Second, few studies have explored the KGMs in the agri-food industry. Most of the studies identified in the literature review focus on the high technology industry, the electronic manufacturing industry, the rail infrastructure industry, and the automotive industry (see Table 1). These industries were selected over the agri-food industry as they are knowledge-intensive, where knowledge creation, sharing, and transferring are more frequent than in other industries (Marra et al. 2012). Recent literature review articles on supply chain KM such as Cerchione and Esposito (2016) showed that most of the papers published in journals are in the subject of computer science, engineering, material sciences, environmental sciences, and business, management and accounting, while only one paper is published in the agricultural and biological science. Their research result indicates a clear need to investigate KGM in the agri-food industry.

- Third, from the research methodological point of view, there is an extensive use of quantitative methods (e.g., structural equation modelling, hierarchical linear modelling, and regression analysis) as shown in Table 1, and only a minority of papers adopt qualitative and mixed-methods. Thus, more research with qualitative methods or mixed-methods is suggested to investigate the KGM in the agri-food industry. 


\begin{tabular}{|c|c|c|c|c|c|c|}
\hline \multirow[t]{2}{*}{ Author(s) (year) } & \multirow[t]{2}{*}{ Industry focus } & \multirow{2}{*}{$\begin{array}{l}\text { Theoretical/ } \\
\text { empirical }\end{array}$} & \multicolumn{3}{|c|}{ Research methodology } & \multirow[t]{2}{*}{ Research methods adopted } \\
\hline & & & Qualitative & Quantitative & $\begin{array}{c}\text { Mixed- } \\
\text { methods }\end{array}$ & \\
\hline Dyer and Nobeoka. (2000) & Automotive industry & Empirical & $\sqrt{ }$ & & & Case study \\
\hline Desouza et al. (2003) & Not specified & Theoretical & $\sqrt{ }$ & & & Literature review \\
\hline Tatikonda and Stock (2003) & High technology industry & Empirical & $\sqrt{ }$ & & & Factor analysis \\
\hline Raisinghani and Meade (2005) & Telecommunication industry & Empirical & & & $\sqrt{ }$ & $\begin{array}{l}\text { Analytic network process } \\
\text { Case study }\end{array}$ \\
\hline Paton and McLaughlin (2008) & Service science industry & Theoretical & $\sqrt{ }$ & & & Case study \\
\hline Lee et al. (2010) & High technology industry & Empirical & & $\sqrt{ }$ & & $\begin{array}{l}\text { Fuzzy Delphi Method } \\
\text { Interpretive structural modelling }\end{array}$ \\
\hline Hernandez-Espallardo et al. (2010) & Apparel industry & Empirical & & $\sqrt{ }$ & & Structural equation modelling \\
\hline Fugate et al. (2012) & $\begin{array}{l}\text { Mass-customized manufacturing } \\
\text { industry }\end{array}$ & Empirical & & $\sqrt{ }$ & & Structural equation modelling \\
\hline Kim et al. (2012) & $\begin{array}{l}\text { Electronic manufacturing } \\
\text { industry }\end{array}$ & Empirical & & $\sqrt{ }$ & & $\begin{array}{l}\text { Regression analysis } \\
\text { Post hoc analysis }\end{array}$ \\
\hline Zhang and Zhou (2013) & $\begin{array}{l}\text { Mechanics, chemicals, plastics, } \\
\text { electronics, furniture industries }\end{array}$ & Empirical & & $\sqrt{ }$ & & Post hoc analysis \\
\hline Kanat and Atilgan (2014) & Clothing industry & Empirical & & $\sqrt{ }$ & & Analytic network process \\
\hline Lu et al. (2014) & Not specified & Empirical & & $\sqrt{ }$ & & Transaction value approach \\
\hline Schoenherr et al. (2014) & Manufacturing industry & Empirical & & $\sqrt{ }$ & & $\begin{array}{l}\text { Confirmatory factor analysis } \\
\text { Structural equation modelling }\end{array}$ \\
\hline Tseng (2014) & Information technology industry & Empirical & & $\sqrt{ }$ & & Pearson's correlation analysis \\
\hline Khan et al. (2015) & Automotive industry & Empirical & & $\sqrt{ }$ & & Structural equation modelling \\
\hline Kim et al. (2015) & Not specified & Empirical & & $\sqrt{ }$ & & Hierarchical linear modelling \\
\hline Lingegard and Lindahl (2015) & Rail infrastructure industry & Empirical & $\sqrt{ }$ & & & Interview and thematic analysis \\
\hline Sangari et al. (2015) & $\begin{array}{l}\text { Mechanical and engineering } \\
\text { industry }\end{array}$ & Empirical & & $\sqrt{ }$ & & Structural equation modelling \\
\hline Rajendran and Rajagopal (2015) & Not specified & Empirical & $\sqrt{ }$ & & & Case study \\
\hline Lim et al. (2017) & Textile industry & Empirical & $\sqrt{ }$ & & & Interpretive structural modelling \\
\hline Ayoub et al. (2017) & Electrical manufacturing industry & Empirical & & $\sqrt{ }$ & & Structural equation modelling \\
\hline Flothmann et al. (2018) & Not specified & Empirical & & $\sqrt{ }$ & & Structural equation modelling \\
\hline Batista et al. (2019) & Agri-food industry & Empirical & $\sqrt{ }$ & & & Case study \\
\hline Rajabion et al. (2019) & Not Specified & Theoretical & $\sqrt{ }$ & & & Systematic literature review \\
\hline
\end{tabular}


A theoretical framework is proposed based on the literature review in the two subsections. Figure 1 demonstrates the relationship between KGMs and AFSC performance in the theoretical framework. There are four KGMs used for enhancing the KM process, as shown in the theoretical framework; these are trust-, reciprocity-, contract-, and market-based KGMs. These four KGMs are selected to build the theoretical framework as it provides more specific categorisations of how to coordinate the behaviours of organisation members. AFSC performance is measured through product quality, process quality, efficiency, flexibility, and responsiveness.
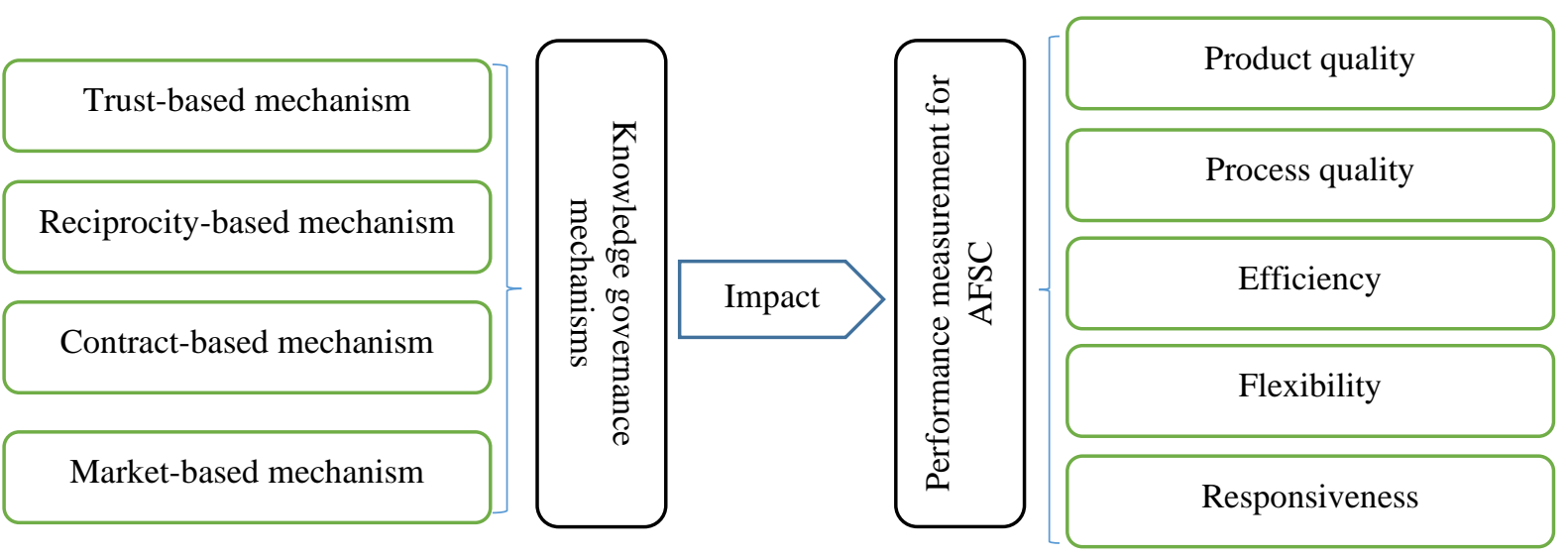

Figure 1 Theoretical framework

\section{Research methodology}

Pragmatism states that the most important determinant of the research philosophy is the research question (Saunders et al. 2019). The research question of this study requires researchers to move back and forth between theoretical and empirical findings. This makes pragmatism appropriate as a basis for research approaches intervening in the world and not merely observing the world (Goldkuhl. 2012). Quantitative approaches are based on deductive reasoning, while qualitative approaches are based on inductive reasoning (Creswell and Plano Clark. 2007). However, pragmatism pertains to use abductive reasoning that integrates qualitative and quantitative approaches in one study (Howe. 1988). Qualitative approaches have proved effective in gaining deep insights and acquiring diversifying views of a certain 
phenomenon through probing a participant's thoughts, values, prejudices, views, feelings and perspectives (Wellington and Szczerbinski. 2007), whereas quantitative approaches have proved appropriate to validate the findings (Hammarberg et al. 2016). Thus, this study is conducted in two separate phases by using a mixed methods research design, aiming at empirically identifying and evaluating the impacts of KGMs on supply chain performance in the agri-food industry. In the qualitative phase, the researcher tries to use participants' views to identify the key themes of KGMs and the AFSC performance metrics, as well as the relationships between KGMs and AFSC performance. This is achieved by using semistructured interviews, thematic analysis, and TISM. In the quantitative phase, empirical findings identified from the qualitative data are evaluated by employing questionnaire-based structured interviews with AFSC experts to check the applicability of the identified relationship between KGMs and AFSC performance for practical use. It is important to note that a mixedmethod approach is applied in this study as it enables us to investigate research issues from different angles, increase validity by combining qualitative and quantitative data, and achieve a holistic view of the issues that are investigated (Doyle et al. 2009; Shaw et al. 2020). As a result, the research methodology implemented in this research consists of three stages (see Figure 2). 


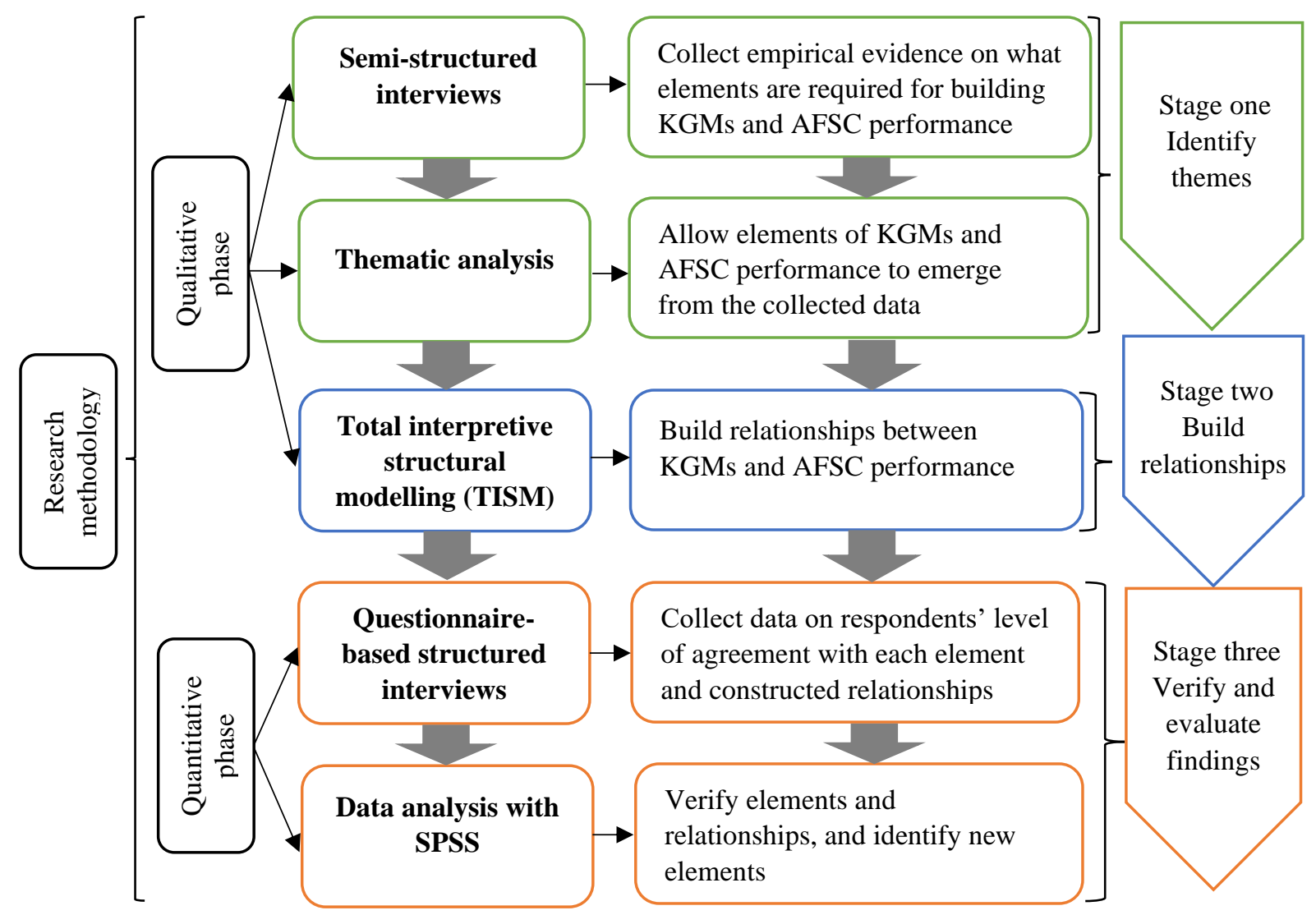

Figure 2 Research methods adopted

As depicted from Figure 2, the three research stages are explained as follows. In the first place, we started with stage one, which aims at identifying key themes of KGMs and AFSC performance. This stage involved face-to-face semi-structured interviews as the data collection method followed by thematic analysis to analyse data. The face-to-face semi-structured interview was chosen over other data collection methods such as observations, telephone interviews, structured interviews, and questionnaires, for several key reasons: (1) face-to-face semi-structured interview was deemed an appropriate data collection method given the goal of obtaining richness in data through insightful discussion with experienced AFSC practitioners (Saunders et al. 2019); (2) face-to-face semi-structured interview helps reveal new themes/knowledge by allowing interviewees to express their ideas freely (King and Horrocks. 2010); (3) face-to-face semi-structured interview is appropriate for the potential participants 
who are not willing to share their personal experience in front of peers, subordinates, and superiors (Sekaran and Bougie. 2013); (4) face-to-face semi-structured interview helps to achieve a high level of interactivity and rich and spontaneous communication between interviewer and interviewee. As Creswell (2009) stated, it encourages two-way communication; and (5) high response rate for the predefined list of questions can be achieved by using faceto-face semi-structured interviews in comparison with other data collection methods (Neuman, 2005). Then, thematic analysis was selected to reveal themes of KGMs and AFSC performance from the data collected through semi-structured interviews. Thematic analysis is a widely used qualitative analytic method, mainly used "for identifying, analysing, and reporting patterns (themes) within data" (Braun and Clarke, 2006, p. 79). The justification for using thematic analysis is based on three key fundamentals. First, thematic analysis is a simpler technique in comparison with content analysis, narrative analysis and discourse analysis. It is easier to use when summarising key features of a large data set. Second, thematic analysis results are easy for the public to understand, particularly those who have a low educational level. Considering that most AFSC practitioners do not receive a higher education (UNESCO, 2017), it would be better to use thematic analysis when we ask AFSC practitioners to verify the thematic analysis results. Third, a high level of flexibility and tangibility can be achieved when using thematic analysis to examine qualitative data (Braun and Clarke, 2006).

Following this, stage two focuses on building the relationships between KGMs and AFSC performance. There are several methods available for building relationships between different variables such as interpretive structural modelling (ISM), DEMATEL (Decision making trail and evaluation laboratory), ANP (Analytic network process), partial least squares structural equational modelling (PLS-SEM), fsQCA (fuzzy-set qualitative comparative analysis), but all these methods have their limitations which make them inappropriate for this study. For example, ISM is useful in forming the relationships between the selected variables, 
but it fails in interpreting the links and thus poses limitations in theory building (Sushil, 2012; Laurie Hughes et al. 2016). DEMATEL is a comprehensive method always used for building causal relationships between/among complex variables (Seleem et al. 2016). However, as this method is normally implemented for solving problems in complicated situations, this may result in imprecise human judgements and vague information (Luthra et al. 2018). ANP is effective in elucidating the interdependencies among the variables, but it has limited applicability due to its complex procedure (Mangla et al. 2018b). Although PLS-SEM and fsQCA can be used in variables' relationship building, they either require a large sample size (at least 200) or are sensitive to case selection (Vis, 2012). Thus, we selected TISM to identify the relationships between KGMs and AFSC performance due to the following reasons. First, TISM is capable of building relationships between variables with the interpretation of links from experts. Hence, it helps answer "what", "why" and "how" questions in theory building (Sushil, 2012; Jena et al. 2017). Second, TISM has the capability to allocate variables into different layers, which helps us to understand the relative importance of the selected variables. Third, TISM, as a qualitative modelling method, has a clear and systematic procedure involving nine steps that make it easy for researchers to implement. Finally, small sample size is enough and limited expertise is sufficient to implement TISM.

The following step in our methodology is stage three, which verifies and evaluates the main findings. We preferred to use the questionnaire-based structured interview rather than the unstructured interview, semi-structured interview, and survey to collect data, for several reasons. First, the questionnaire-based structured interview is suitable for collecting data where there are a number of standardised questions to be answered (Saunders et al. 2019). Currently, appropriate 40 elements are identified for KGMs and AFSC performance, and 20 relationships built between different KGMs and AFSC performance categories need to be verified and evaluated in this stage. Hence, the situation makes unstructured and semi-structured interviews 
not applicable to this research stage. Second, managers, directors, presidents and vicepresidents are more likely to agree to be interviewed, rather than complete a questionnaire, particularly on a topic relevant to their current work (North et al. 1983). Finally, a higher response rate and a more reliable answer can be acquired in comparison with using surveys to collect data, as the interviewer needs to read out each question and then record the response following a standardised schedule (Saunders et al. 2019). Thus, we selected the questionnairebased structured interview to verify and evaluate the findings.

\section{Empirical data collection}

The empirical data collection was conducted in four different countries (Argentina, France, Italy, and Spain) with 22 AFSC experienced practitioners from April 2017 to July 2019, which is framed under the international and competitive H2020 RUC-APS research project (Hernandez et al. 2017). As these four countries are located in both the southern and northern hemispheres with different climates that can provide a wide variety of AFSC for the research, it was important for the authors to visit them to investigate the impact of KGMs on AFSC performance. Furthermore, knowledge-intense agricultural activities such as planting, control pests and diseases, and harvesting, mostly take place during the spring, summer, and autumn, which determined that the authors should visit these four countries in different seasons. The interviews with experienced AFSC practitioners provided fruitful insights into which elements are useful for building different KGMs and AFSC performance, and how AFSC performance is improved depending on which KGMs is implemented.

Purposive sampling and snowball sampling (Saunders et al. 2019) were used to recruit suitable interview participants in the empirical data collection. Specific criteria for recruiting appropriate interview participants are: (1) The interviewees should come from the agri-food industry and be directly involved in the KM of AFSC and AFSC performance management. 
Furthermore, interviewees from different sectors and diverse patterns of AFSC (e.g., farmers, cooperatives, processors, wholesalers, distributors and retailers) are required to ensure diverse backgrounds and knowledge. As recommended by Shaw et al. (2020), this arrangement is useful for building new ideas and encouraging participants to think from different angles. (2) The interviewees should have at least 10 years of work experience on the KM of AFSC and AFSC performance management, to ensure that interviewees have high levels of skills and more refined experience, or expertise. (3) The selected company must be either a medium(between 10 and 249 employees) or large-sized company (more than 249 employees), since these companies have rich experience and deep understanding of KM and AFSC performance management. Based on the criteria, initially, face-to-face semi-structured interviews were carried out with 19 experienced AFSC practitioners who were considered knowledgeable about KM and AFSC performance management. Then, snowball sampling was used to recruit additional participants. Based on the above criteria, some participants either failed in the criteria of company size or failed in the criteria of working experience, which left only three participants available for further interviews. After conducting three additional interviews, the data saturation point was reached as no new themes emerged from the interviews. Thus, we stopped conducting further interviews, which made the total sample size of 22 participants. Appendix A provides an overview of companies and interviewees. Each interview lasted for 90 minutes on average to allow participants enough time to express their ideas on KGMs and AFSC performance management.

An interview template was developed and included questions to obtain the experienced AFSC practitioners' opinions on what elements are used for building KGMs and AFSC performance, and how AFSC performance can be achieved through implementing different KGMs. One professor in operations management and two practitioners in AFSC were invited to review the interview template and participate in the pilot testing to confirm whether the 
coverage and relevance of the content are appropriate or not, and to identify the questions that needed to be reformulated. The modifications and corrections were minor, most focused on rewording and changing the order of questions to ensure potential participants understand easily. To ensure the validity and reliability of interviews, a round table meeting was conducted before each interview to explain KGMs and supply chain performance management to the interviewees. During each interview, interviewees were encouraged to express their ideas with respect to the context being discussed. An interview template was used as a guide to keep the focus of the discussion on the subject. Probing questions were asked to get interviewees to clarify their answers as necessary. There were two researchers involved in each of the interviews; each took notes, and the interviews were recorded through a digital voice recorder with the permission of interviewees. After each interview, we emailed the interviewees with transcripts and notes taken during interviews to ensure that we have understood the interviewees' opinions correctly. Thus, we ensured that no important information was missed, and data validity and reliability were achieved (Kumar et al. 2019). To further ensure data validity and reliability, non-verbal behaviours of interviewees were also taken into consideration when transcribing data (Kvale and Brinkmann. 2009). Simultaneously, we undertook extensive site tours and collected large amounts of documentary materials (e.g., enterprise brochures, policy documents, and quality standards) related to KM and AFSC performance to achieve data triangulation.

\section{Data analysis, findings, and evaluation}

This section presents how the data are analysed and evaluated. Thematic analysis was used for generating various themes related to KGMs and AFSC performance. Then, TISM was performed to build relationships between KGMs and AFSC performance. Finally, feedback 
was collected through questionnaire-based structured interviews to evaluate the empirical and theoretical findings.

\subsubsection{Themes generated through thematic analysis}

The empirical data collected through semi-structured interviews were analysed by using thematic analysis. This is a widely used approach to analyse qualitative data, mainly used for identifying common topics, ideas and patterns of meaning that are found across the entire interview or set of interviews (Braun and Clarke, 2006). Furthermore, the thematic analysis helped to find the data saturation point, meaning no more interviews were carried out. It consists of six steps: familiarisation with the data, generating initial codes, searching for themes, reviewing themes, defining and naming themes, and writing up (see Figure 3). In the first step of familiarisation with the data, three key activities were conducted: transcribing interview audio files word-by-word, immersive reading and re-reading transcripts, and noting down the theoretical and reflective thoughts through immersion in the data. Afterwards, we worked systematically through entire data sets and code in as many patterns as possible to identify potential elements of KGMs and performance indicators of AFSC. In this step, NVivo 12 software program was used to sort and organise the large data set. The credibility of analysis was achieved by having two independent researchers analyse each data set simultaneously. Then, themes were identified by merging all the codes or components or fragments of ideas or experiences together. After reviewing the themes, two researchers involved in the semistructured interview revisited all the themes carefully to ensure that the words were used for each theme precisely. For example, building a partnership in the trust KGM category was renamed as building a project partnership.

Throughout the thematic analysis, several themes were identified by considering the following three stages highlighted by King and Horrocks (2010): 
- Descriptive coding (first-order codes): the researchers identify those parts of the transcript data that address the research questions and allocate descriptive codes throughout the whole transcript.

- Interpretative coding (second-order themes): the researchers group together descriptive codes that seem to share some common meaning and create an interpretive code that captures this.

- $\quad$ Defining overarching themes (aggregate dimensions): the researchers identify a number of overarching themes that characterise key concepts in the analysis. The second-order themes were identified using first-order codes and they were categorised as aggregated dimensions to reveal the elements of KGMs and AFSC performance. The empirical evidence in discovering KGMs and AFSC performance indicators are shown in Appendix B and Appendix C, respectively. The thematic analysis reveals 15 elements of KGMs such as building a project partnership, building an equal relationship, rewards, and fewer intermediaries, among others. The 15 elements can be categorised into four categories trust-, contract-, reciprocity-, and market-based KGMs. As for the thematic analysis results of AFSC performance indicators, we identified 26 elements (e.g., waste reduction, traceability, water quality, packaging, and volume flexibility) which are categorised into five categories product quality, efficiency, flexibility, process quality, and responsiveness. 


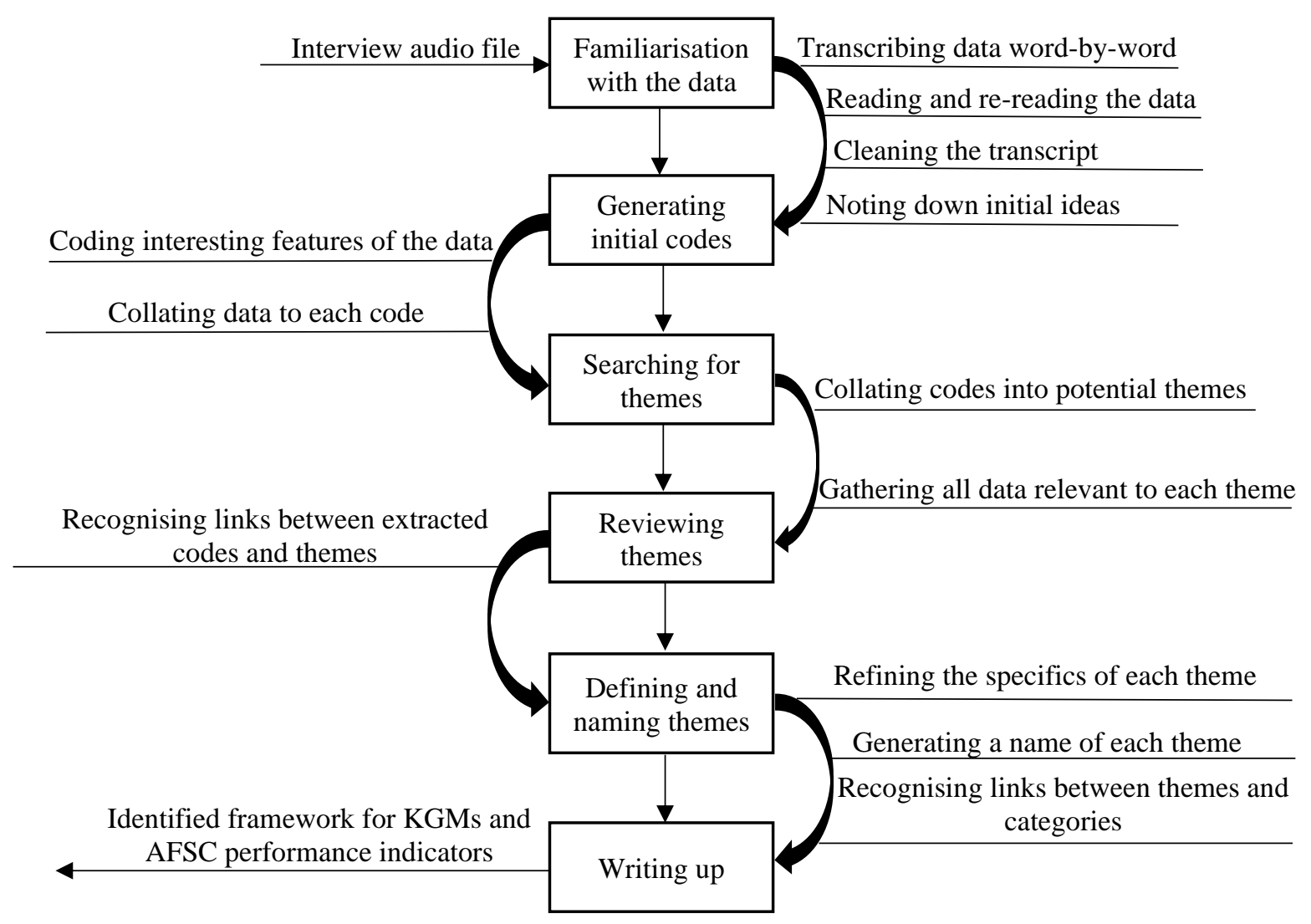

Figure 3 Thematic analysis process

\subsubsection{Building relationships between KGMs and AFSC performance through TISM}

TISM was used to build the relationships between KGMs and AFSC performance categories. AFSC performance categories rather than performance indicators were selected to build relationships with KGMs as the TISM process is more difficult to use when the number of variables increases. Therefore, researchers are advised to limit the number of variables to be applied in TISM (Shibin et al. 2016; Jena et al. 2017). The TISM process comprises nine steps (Sushil, 2012):

Step I Identify and define the elements. Four KGMs (trust-based, reciprocity-based, contract-based, and market-based KGMs) and five AFSC performance categories (product 
quality, process quality, efficiency, flexibility, and responsiveness) were used as inputs to perform TISM.

Step II Determine the context relationship. To build the relationship between KGMs and AFSC performance categories, the contextual relationship between KGMs and AFSC performance categories is defined as "element A should/will help achieve element B".

Step III Interpret the relationship. Four experts from the agri-food industry (selected from the interviewees) were chosen based on the team syntegrity methodology proposed by Beer (1994). Suitable experts were selected based on their interests in AFSC KM. If the contextual relationship pertains yes, "in what way element A should/will help achieve element B" will also be asked. Experts' interpretation of the relationship would help to deepen our understanding and help us to manage these elements (Sushil. 2012; Jena et al. 2017).

Step IV Interpret logic of pair-wise comparison. Each element is individually compared with all the other elements. Thus, there will be $72(n \times(n-1)$, where $n$ represents the quantity of elements) numbers of rows in the knowledge base to perform this study. An "interpretive logic knowledge base" is developed for pair-wise comparison of identified elements. Based on the experts" opinion, if there is a relationship between two identified elements, code "Y" for yes is represented and the relationship is further interpreted. Conversely, code " $\mathrm{N}$ " for no is represented.

Step V Reachability matrix and transitivity check. The initial reachability matrix (see Table 2) is developed with the help of the interpretive logic-knowledge base by denoting 1 if there is code "Y"; otherwise 0 if there is code "N". Then, the initial reachability matrix is checked for transitivity rule. If element A relates to element B and element B relates to element $\mathrm{C}$, then element A necessarily relates to element $\mathrm{C}$. The final reachability matrix is shown in Table 3. 
Table 2 Initial reachability matrix

\begin{tabular}{cccccccccc}
\hline & E1 & E2 & E3 & E4 & E5 & E6 & E7 & E8 & E9 \\
\hline E1 & 1 & 1 & 0 & 1 & 1 & 1 & 1 & 1 & 1 \\
\hline E2 & 1 & 1 & 0 & 1 & 1 & 1 & 1 & 1 & 1 \\
\hline E3 & 0 & 1 & 1 & 1 & 1 & 1 & 1 & 1 & 1 \\
\hline E4 & 1 & 1 & 0 & 1 & 1 & 1 & 1 & 1 & 1 \\
\hline E5 & 0 & 0 & 0 & 0 & 1 & 0 & 0 & 0 & 1 \\
\hline E6 & 0 & 0 & 0 & 0 & 1 & 1 & 0 & 1 & 1 \\
\hline E7 & 0 & 0 & 0 & 0 & 1 & 1 & 1 & 0 & 0 \\
\hline E8 & 0 & 0 & 0 & 0 & 0 & 0 & 0 & 1 & 1 \\
\hline E9 & 0 & 0 & 0 & 0 & 0 & 0 & 0 & 0 & 1 \\
\hline
\end{tabular}

Table 3 Final reachability matrix

\begin{tabular}{cccccccccc}
\hline & E1 & E2 & E3 & E4 & E5 & E6 & E7 & E8 & E9 \\
\hline E1 & 1 & 1 & 0 & 1 & 1 & 1 & 1 & 1 & 1 \\
\hline $\mathbf{E 2}$ & 1 & 1 & 0 & 1 & 1 & 1 & 1 & 1 & 1 \\
\hline $\mathbf{E 3}$ & $1^{*}$ & 1 & 1 & 1 & 1 & 1 & 1 & 1 & 1 \\
\hline $\mathbf{E 4}$ & 1 & 1 & 0 & 1 & 1 & 1 & 1 & 1 & 1 \\
\hline $\mathbf{E 5}$ & 0 & 0 & 0 & 0 & 1 & 0 & 0 & 0 & 1 \\
\hline $\mathbf{E 6}$ & 0 & 0 & 0 & 0 & 1 & 1 & 0 & 1 & 1 \\
\hline $\mathbf{E 7}$ & 0 & 0 & 0 & 0 & 1 & 1 & 1 & $1 *$ & $1 *$ \\
\hline $\mathbf{E 8}$ & 0 & 0 & 0 & 0 & 0 & 0 & 0 & 1 & 1 \\
\hline E9 & 0 & 0 & 0 & 0 & 0 & 0 & 0 & 0 & 1 \\
\hline
\end{tabular}

Note: * represents transitivity

Step VI Level determination by partitioning reachability matrix. The level partitioning is performed until the level of each element is determined and illustrated in Appendix D.

Step VII Develop digraph. All the elements are depicted in the form of a digraph. Important transitive links are represented with dotted lines.

Step VIII Develop interpretive matrix. A binary interaction matrix is developed by translating all interactions of digraph by 1 in the respective cell.

Step IX Total interpretive structural model. The TISM model (see Figure 4) is developed by using the information in the interpretive matrix and digraph. The interpretation of each link was written on the line representing the respective links in the TISM hierarchy model. 


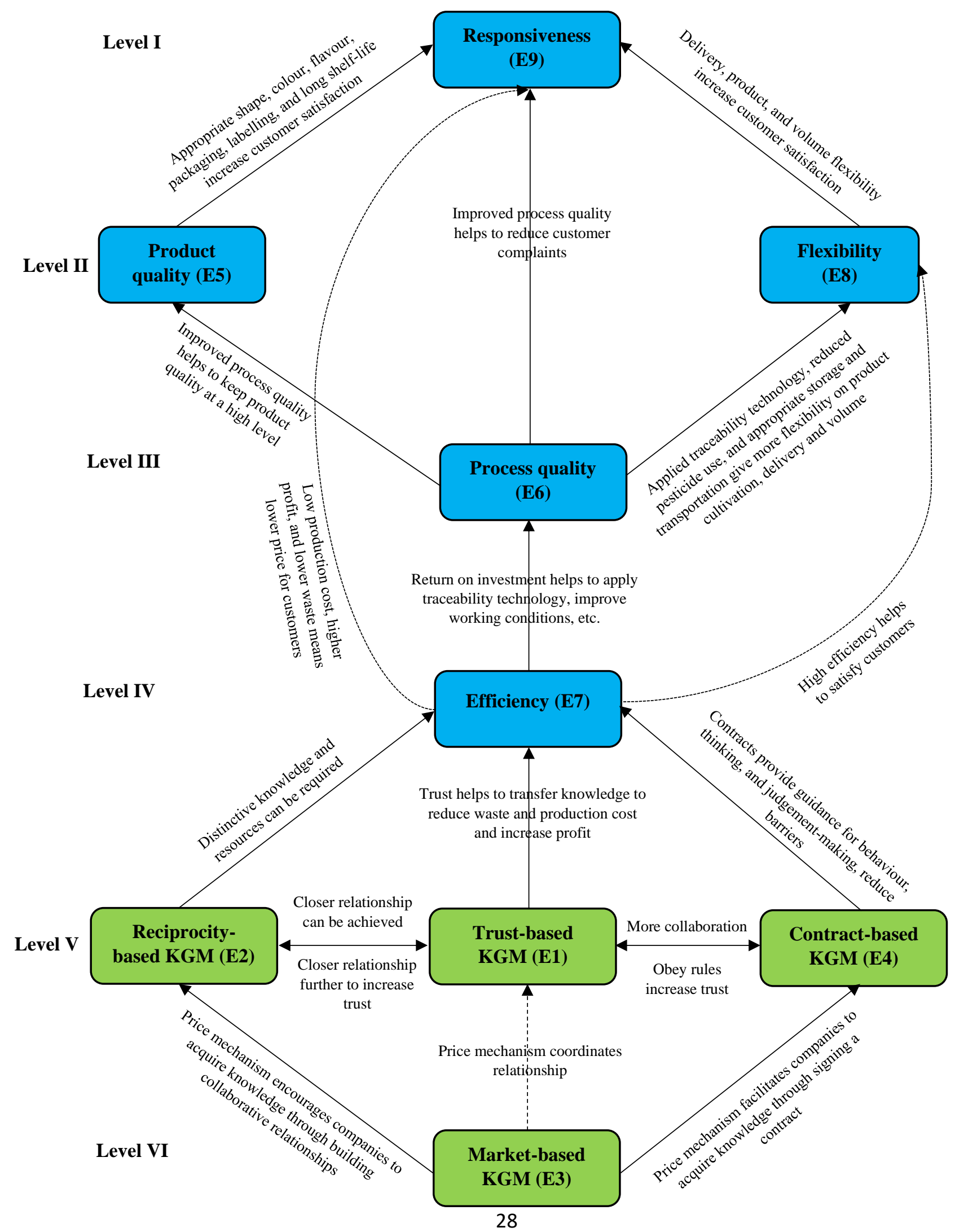


Figure 4 TISM model of KGMs and AFSC performance

One of the key objectives of this research is to identify the relationship between different KGMs and AFSC performance. As shown in Figure 4, market-based (E3), trust-based (E1), contract-based (E4), and reciprocity-based (E2) KGMs constitutes levels five and six of the TISM-based model, while the AFSC performance categories such as efficiency (E7), process quality (E6), product quality (E5), flexibility (E8), and responsiveness (E9) occupy levels four to one in the TISM model. The TISM model of KGMs and AFSC performance clearly shows that KGMs have an impact on AFSC performance. The lower-level KGMs are the driving forces behind the higher level of AFSC performance.

\subsubsection{Verify and evaluate the findings using questionnaire-based structured interviews}

To test the above theoretical and empirical findings, questionnaire-based structured interviews were conducted in November 2019 in Chile with four experienced AFSC experts from academia and the agri-food industry. These four experienced AFSC experts were selected based on the team syntegrity methodology (Beer, 1994), which is particularly useful in supporting teamwork related to knowledge acquisition (Espinosa and Harnden, 2006). First, a round table meeting was organised in Chile with a focus on the general topic of KM in AFSC. Second, participants' concerns regarding the general topic were clustered into 12 sub-topics such as knowledge mobilisation crossing boundaries, AFSC performance, and knowledge transfer in AFSC, among others. Third, the participants' indicated which subtopics they would like to discuss the most, and teams were formed according to this criterion. As four experienced AFSC experts expressed interests in the subtopic of the impact of KGMs on AFSC performance, these experts were selected for questionnaire-based structured interviews. All the selected experts have been working in the field of AFSC for more than 10 years, and have expertise in 
AFSC sustainable management, pesticide residue in agri-food, plant breeding, and AFSC information technology, respectively. Chile was selected to verify and evaluate theoretical and empirical findings as it is located in South America, and its agricultural industry is one of the backbones of Chile's economy. The agriculture industry is responsible for $28 \%$ of the total Chilean trade, as well as $11 \%$ of its total GDP. Furthermore, $20 \%$ of Chile's labour force is engaged in agriculture (USDA Foreign Agricultural Service, 2017). The critical role of the agriculture industry in Chile provided us an excellent opportunity to evaluate the elements of KGMs and AFSC performance and their relationships. Pilot tests were conducted with one professor in operations management and two doctors from the Agri-food Research Institute of Chile; their comments were minor. Detailed explanations on the topic, related definitions, and vivid examples were given before the interview session to ensure that interviewees had sufficient understanding of this research. All feedback was collected and recorded manually, on paper in the form of questionnaires and then entered into the statistical software SPSS. The questionnaire used for the structured interviews is in Appendix E. Each interview lasted between 45 and 60 minutes. The feedback from the structured interviews is summarised below:

- First, almost all the respondents agree or strongly agree on the elements of different KGMs. All statements rated relatively positive, indicating the respondents highly agree with the elements identified in the empirical findings. However, one of the four respondents holds neutral on building a project partnership of trust-based KGM. The respondent supposed that it is difficult for the participants to build solid relationships with other project partners, particularly in a large or huge project. Most participants do not have a chance to talk with other project partners even when the project is completed.

- Second, all respondents agree or strongly agree on the elements identified for evaluating AFSC performance. They further elaborated that all the elements are more suitable for evaluating the performance of Chilean food exportation as the Chilean 
government imposed strict standards for ensuring the food quality and process quality to satisfy their international customers. A new element - food safety and maximum residues limits (MRLs) of pesticides compliance (FS-MRLs pesticides compliance) - was suggested by our respondents to be included in the product quality to evaluate the AFSC performance.

- Third, the questions were presented in a five-point Likert scale format (Likert, 1932) in this section to test respondents' level of agreement with each relationship captured from the previous research stages, and with anchors of 1 agree to 5 strongly agree. All the respondents marked 3 or 4 or 5 in each cell, indicating a high level of agreement on the relationship between KGMs and AFSC performance. Also, the participating experts hold the view that KGMs can help to increase profits, efficiency, and performance of AFSC by encouraging AFSC practitioners to acquire more knowledge from their partners, NGOs (non-profit organisations), and agri-food research institutes. The knowledge acquired from others and applied in their business helps them to perform better.

The evaluation conducted in Chile shows that all the elements of KGMs and AFSC performance identified through semi-structured interviews and thematic analysis are suitable for Chilean food exportation supply chains. Furthermore, the inclusion of a new element, $F S$ MRLs pesticide compliance was strongly suggested in the category of product quality, as pesticide residue is difficult to examine and is easily neglected by the domestic AFSC. The relationship built between KGMs and AFSC performance through TISM was evaluated by experienced AFSC experts as appropriate, as KGMs can facilitate knowledge mobilisation in the AFSC, further increasing AFSC performance. Based on the evaluation results, the evaluated theoretical framework has been built (see Figure 5), including elements for building KGMs and AFSC performance, as well as the relationship between KGMs and AFSC performance. 


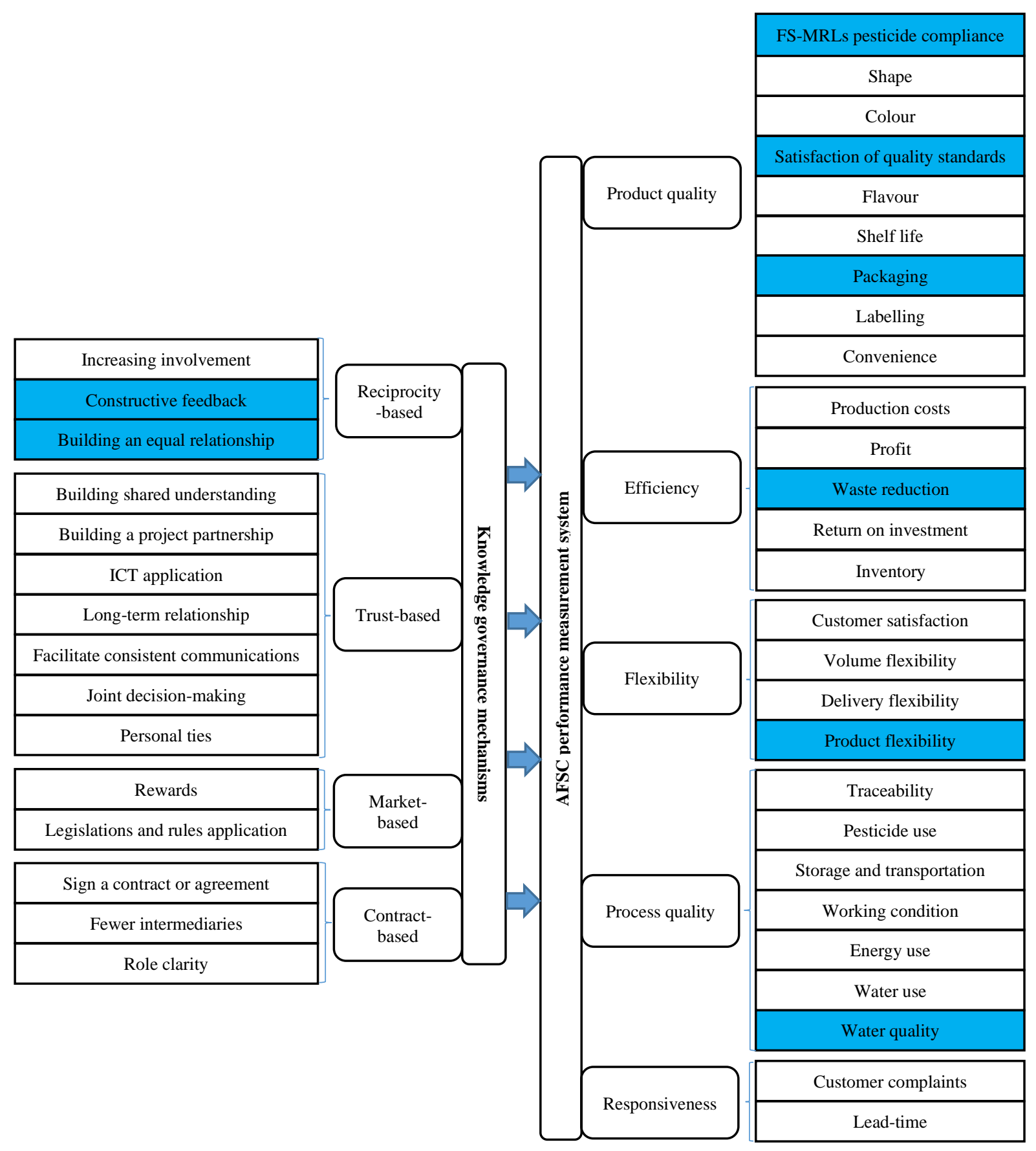

Figure 5 The evaluated theoretical framework (Note: Blue represents new elements)

\section{Discussion and implications}

Different elements of KGMs and AFSC performance were revealed through thematic analysis with the data collected from experienced AFSC practitioners. For example, seven elements (e.g., facilitate consistent communications, personal ties, and building project partnership) 
were identified as having positive effects in building trust-based KGM. Earlier work has only indicated that trust can be significantly improved by effective communication, positive past collaboration, existing relationships, ICT application, third party referrals and shared values (Das and Teng, 2001; Bstieler, 2006; Cheng et al. 2008), whereas personal ties and project partnership do not seem to have a significant effect (Fischer, 2013). However, the empirical findings of this study reveal that personal ties and building a project partnership help to build trust significantly. The development of a project partnership requires partners to learn other's operations and expertise in order to improve whole project performance. In Argentina and Chile, trust building is a real management concern as most of the AFSC practitioners are reluctant to share knowledge because of the lack of confidence and trust. Among the three elements for building reciprocity-based KGM, building an equal relationship and constructive feedback are new factors in building reciprocal relationships. The benefits of constructive feedback have been highlighted in the area of total quality management (TQM), team working, empowerment, and organisational performance (Roebuck, 1996). The study carried out by Buckley et al. (2006) illustrated that equal relationships built on personal trust were essential to keep the company functioning. However, building an equal relationship and constructive feedback seem to be neglected by researchers in building reciprocity-based KGM. The empirical findings of this study indicate that equal relationship helps to reduce discrimination between researchers and farmers, which makes farmers more active in the research process. Therefore, farmers are more willing to contribute and researchers are more likely to share their knowledge with farmers. Among the elements of market-based and contract-based KGMs, the majority of elements are new to the KGMs. However, there are several elements that support the literature. Bock et al. (2005) highlighted the important role of rewards and incentives in supporting knowledge workers to exploit and create knowledge, which is reinforced by this study. The empirical findings of this study indicate that the quality certificate acquired by 
AFSC practitioners will force other AFSC practitioners to learn new knowledge. Fang et al. (2013) indicated the importance of role clarity and application of legislations and rules in the KGMs. This study also supports this point. Smedlund (2006) revealed the important role of intermediaries in forming innovation strategies and transferring knowledge in the regional system, but the findings of this study show that intermediaries' effect is weakened as most farmers in Argentina and Chile are more likely to sign a contract with private research institution directly to acquire knowledge.

Among the identified elements for building AFSC PMS, a minority of elements can be seen as new elements for building AFSC PMS; for example, packaging and quality standards, and FS-MRLs pesticide compliance in the product quality category, water quality in the process quality category, waste reduction in the efficiency category, and product flexibility in the flexibility category. Beitzen-Heineke et al. (2017) pointed out the importance of using alternative packaging material in the AFSC to induce resource efficiency and ensure higher transparency. The empirical findings of this study witnessed that woods and degradable papers are frequently used in packaging in terms of more strict environmental standards. Aramyan et al. (2007) highlighted that appearance, taste, shelf life, safety and convenience are used for building AFSC PMS, but the findings of this study show that, besides these elements, quality standards, water quality, waste reduction, FS-MRLs pesticide compliance and product flexibility are also essential for building AFSC PMS. Currently, increasing attention from academia and the agri-food industry is being given to the application of lean principles in AFSC to reduce food waste (Vlachos, 2015), our empirical findings support this point. In order to reduce food waste, the investigated company in southern France donates low-quality fresh vegetables to charities or homeless people. Kotsanopoulos and Arvanitoyannis (2017) illustrated that different food quality standards (e.g., ISO 9001) have been applied in the agrifood industry, but none of them has been applied into AFSC PMS to evaluate AFSC 
performance. The empirical findings from Chile demonstrate that quality standards should be used for building AFSC PMS, particularly for the Chilean food exportation supply chains.

Furthermore, the TISM analysis shows that market-based KGM forms the lowest level in the TISM-based model, and should be given critical focus, as it acts as a key driving force behind achieving higher levels of AFSC performance. Price enables high-powered incentives that encourage companies or partners to search for, exploit, and create new knowledge through building reciprocity and trust relationships or signing a contract with other companies. Once the collaborative relationship has been built, different types of knowledge can be acquired; for example, packaging knowledge, market requirements, customer preferences, and knowledge about the potential added-value of foods. Companies take advantage of the knowledge acquired from other partners to develop environmental packages and new labelling, foster a new generation of seeds, reduce pesticide use, and improve the working conditions of employees, among other initiatives, meaning that production cost reduction, waste reduction, and profit enhancement can be achieved. In other words, a higher portion of profit can be used to apply new traceability technology, improve irrigation systems, and upgrade storage and transportation systems. Due to these improvements, higher product quality and greater flexibility can be achieved. Finally, they can help to reduce customer complaints and lead-time to improve AFSC responsiveness because of high product quality and flexibility in satisfying customer requirements.

Besides the contribution to theory, this study also has a number of contributions to AFSC stakeholders. First, various elements of different KGMs were identified through empirical findings. Thus, AFSC stakeholders can facilitate knowledge transfer between/among partners that incorporate the development of different KGMs. For example, signing a technology/knowledge transfer contract, building reciprocal relationships, increasing trust or buying patents at market prices are all effective when AFSC stakeholders want to acquire 
distinctive knowledge and technologies from their partners. Competing in today's dynamic market, firms that seek to build their core competency should implement different KGMs to acquire more valuable knowledge. Second, another significant insight from this study is that AFSC stakeholders should focus on improving AFSC performance from different perspectives, including product quality, efficiency, flexibility, process quality and responsiveness. Our study reveals that 27 elements have positive effects on AFSC performance enhancement, such as packaging, product shape, pesticide use, waste reduction, and lead-time. For example, waste is a serious problem in the countries where empirical studies have been conducted. Therefore, AFSC practitioners need to seek methods to reduce waste to increase their performance. Feasible methods include selling imperfect vegetables to the secondary market or donating the vegetables to poor people or charity organisations. Potential contributions also include the fact that AFSC stakeholders can focus on specific elements for improving AFSC performance. This will reduce the time and effort required if the target is set initially. Third, our findings reveal that AFSC stakeholders have priorities for building KGM and improving AFSC performance. That is, they should focus on market-based KGM to facilitate knowledge transfer and efficiency for improving AFSC performance. Therefore, set rewards for their staff should be applied in their organisation if they make a breakthrough in knowledge or technology. They can strengthen efficiency in AFSC performance by reducing production costs and increasing profits by applying different technologies, building relationships with the leading company in their field to improve return on investment. It is important to note that the companies we investigated also consider it important to build stable relationships with the leading company or research institute to acquire knowledge for improving performance. The leading company has a core position in its local AFSC; therefore, it can integrate resources to improve the whole chain's performance. Through strengthening staff exchange, building a common knowledge 
repository, and implementing common agri-food quality standards and traceability systems, the whole AFSC performance can be improved over time.

\section{Conclusion and future research directions}

This study uses a mixed-method approach to investigate the impacts of KGMs on AFSC performance. Empirical data were collected with experienced AFSC practitioners from Argentina, France, Italy, and Spain using semi-structured interviews. Then, thematic analysis was used to generate elements of different KGMs and AFSC performance. Afterwards, the relationship between KGMs and AFSC performance was constructed through TISM. Finally, questionnaire-based structured interviews were further conducted in Chile to verify and evaluate the theoretical and empirical findings. The research results indicate that market-, trust-, reciprocity-, and contract-based KGMs have positive effects on different dimensions of AFSC performance, including product quality, process quality, efficiency, flexibility, and responsiveness. The outcome of this study also reveals that market-based KGM should be given critical focus as it is located at the lowest level in the TISM model.

The authors recognise that the study has a few limitations. First, while the authors have collected empirical data on the elements of different KGMs and AFSC PMS from Argentina, France, Italy, and Spain, we do not know which elements should be given priority to be implemented as each AFSC practitioner does not have unlimited resources. Second, questionnaire-based structured interviews were used to verify and evaluate the research result with experienced AFSC practitioners from Chile. However, other actors' opinions, including seed providers, agri-chemical providers, wholesalers, distributors, retailers, and consumers on the research results, were missing. Third, given that the research results were evaluated in Chile, the evaluation results show that the elements of AFSC PMS are only suitable for Chilean exportation AFSC. Thus, caution is needed when generalising the results. Based on the 
aforementioned discussions on the limitations of this paper, three corresponding research direction are proposed:

- In order to determine which elements have priority or the sequence to be implemented, we suggest the use of an analytic hierarchy process (AHP). AHP is a multicriteria rank method proposed by Saaty (1977), which enables the decision-maker to structure a complex problem in the form of a simple hierarchy and assess a large number of quantitative and qualitative factors in a systematic manner.

- In order to obtain comprehensive responses from a wider audience in the AFSC of Chile, we suggest that questionnaires are sent to other actors of AFSC.

- To test generalisability of the research results, we suggest that other countries such as China and Brazil are included in further research to evaluate the AFSC performance from the perspectives of domestic AFSC and exportation AFSC. Brazil is suggested as it is the largest country in South America and a leading exporter of a wide range of crops (e.g., oranges, soybeans, coffee, and cassava) (Brazil, 2010). China is selected as the agriculture industry plays a vital role in China, employing over 300 million farmers (Food and Agriculture Organization of the United Nations, 2019).

Acknowledgment The work reported in this paper has benefited from the RUC-APS project funded by the European Commission under the Horizon 2020 Programme (H2020-MSCARISE Award No. 691249).

\section{References:}

Abid, M., Ali, B. 2014. Antecedents and effectiveness of CKM: an empirical study. Journal of Basic and Applied Scientific Research 4(1), pp. 104-117.

Aboelmaged, M.G. 2014. Linking operations performance to knowledge management capability: the mediating role of innovation performance. Production Planning and Control 25(1), pp. 44-58.

Agarwal, A., Shankar, R., Tiwari, M.K. 2006. Modeling the metrices of lean, agile and leagile supply chain: an ANP-based approach. European Journal of Operational Research 173(1), pp. 211-225. 
Angelis, R.D., Howard, M., Miemczyk, J. 2018. Supply chain management and the circular economy: towards the circular supply chain. Production Planning \& Control 29(6), pp. 425437.

Aramyan, L.H., Oude Lansink, A.G.J.M., van der Vorst, J.G.A.J., van Kooten, O. 2007. Performance measurement in agri-food supply chains: a case study. Supply Chain Management: An International Journal 12(4), pp. 304-315.

Ayoub, H.F., Abdallah, A.B., Suifan, T.S. 2017. The effect of supply chain integration on technical innovation in Jordan: the mediating role of knowledge management. Benchmarking: An International Journal 24(3), pp. 594-616.

Batista, L., Dora, M., Toth, J., Molnar, A., Malekpoor, H., Kumari, S. 2019. Knowledge management for supply chain synergies - a maturity level analysis of SME companies. Production Planning and Control 30(10-12), pp. 995-1004.

Beamon, B.M. 1999. Measuring supply chain performance. International Journal of Operations and Production Management 19(3), pp. 275-292.

Beer, S. 1994. Beyond dispute: the invention of team syntegrity. Chichester: Wiley.

Beitzen-Heineke, E.F., Balta-Ozkan, N., Reefke, H. 2007. The prospects of zero-packaging grocery stores to improve the social and environmental impacts of the food supply chain. Journal of Cleaner Production 140, pp. 1528-1541.

Blome, C., Schoenherr, T., Eckstein, D. 2014. The impact of knowledge transfer and complexity on supply chain flexibility: a knowledge-based view. International Journal of Production Economics 147, pp. 307-316.

Bock, G.W., Zmud, R.W., Kim, Y.G., Lee, J.N. 2005. Behavioural intention formation in knowledge sharing: examining the role of extrinsic motivators, social-psychological forces, and organizational climate. MIS Quarterly 29(1), pp. 87-111.

Bonte, W. 2008. Inter-firm trust in buyer-supplier relations: are knowledge spillovers and geographical proximity relevant? Journal of Economic Behavior and Organization 67(3-4), pp. 855-870.

Braun, V., Clarke, V. 2006. Using thematic analysis in psychology. Qualitative Research in Psychology 3(2), pp. 77-101.

Brazil. 2010. Available at: https://www.brazil.org.za/agriculture.html [Accessed: 12/12/2019].

Bstieler, L. 2006. Trust formation in collaborative new product development. Journal of Product Innovation Management 1(1), pp. 56-72.

Buckley, P.J., Clegg, J., Tan, H. 2006. Cultural awareness in knowledge transfer to China - the role of guanxi and mianzi. Journal of World Business 41, pp. 275-288.

Bunduchi, R. 2013. Trust, partner selection and innovation outcome in collaborative new product development. Production Planning \& Control 24(2-3), pp. 145-157.

Cao, Y., Xiang, Y. 2012. The impact of knowledge governance on knowledge sharing. Management Decision 50(4), pp. 591-610. 
Cerchione, R., Esposito, E. 2016. A systematic review of supply chain knowledge management research: State of the art and research opportunities. International Journal of Production Economics 182, pp. 276-292.

Chae, B. 2009. Developing key performance indicators for supply chain: an industry perspective. Supply Chain Management: An International Journal 14(6), pp. 422-428.

Cheng, J.H., Yeh, C-H., Tu, C-W. 2008. Trust and knowledge sharing in green supply chains. Supply Chain Management: An International Journal 13(4), pp. 283-295.

Chen, H., Liu, S., Zhao, G., Oderanti, F., Guyon, C., Boshkoska, B.M. 2019. Identifying knowledge brokers, artefacts and channels for waste reduction in agri-food supply chains. International Journal of Sustainable Agricultural Management and Informatics 4(3), pp. 273 289.

Choi, C.J., Cheng, P., Hilton, B., Russell, E. 2005. Knowledge governance. Journal of Knowledge Management 9(6), pp. 67-75.

Clark, W.C., van Kerkhoff, L., Lebel, L., Gallopin, G.C. 2016. Crafting usable knowledge for sustainable development. Proceedings of the National Academy of Sciences 113(17), pp. 45704578 .

Creswell, J.W., Plano Clark, V.L. 2007. Designing and conducting mixed methods research. Thousand Oaks, CA: Sage Publications.

Creswell, J.W. 2009. Research design: qualitative, quantitative, and mixed methods approaches, 3rd ed. Thousand Oaks, CA: Sage Publications.

Das, T.K., Teng, B-S. 2001. Trust, control, and risk in strategic alliances: an integrated framework. Organization Studies 22(2), pp. 251-283.

Desouza, K.C., Chattaraj, A., Kraft, G. 2003. Supply chain perspectives to knowledge management: research propositions. Journal of Knowledge Management 7(3), pp. 129-138.

Dey, P.K., Cheffi, W. 2013. Green supply chain performance measurement using analytic hierarchy process: a comparative analysis of manufacturing organisations. Production Planning \& Control 24(8-9), pp. 702-720.

Dinu, M.D. 2016. Supply chain performance within agri-food sector. Economics of Agriculture 63(3), pp. 919-928.

Dooley, L., Kirk, D., Philpott, K. 2013. Nurturing life-science knowledge discovery: managing multi-organization networks. Production Planning and Control 24(2-3), pp. 195-207.

Doyle, L., Brady, A-M., Byrne, G. 2009. An overview of mixed methods research. Journal of Research Nursing 14(2), pp. 175-185.

Dyer, J.H., Nobeoka, K. 2000. Creating and managing a high-performance knowledge-sharing network: the Toyota case. Strategic Management Journal 21, pp. 345-367.

Espinosa, A., Harnden, R. 2006. Team syntegrity and democratic group decision making: theory and practice. Journal of the Operational Research Society 8(58), pp. 1-9. 
Fang, S-C., Yang, C-W., Hsu, W-Y. 2013. Inter-organisational knowledge transfer: the perspective of knowledge governance. Journal of Knowledge Management 17(6), pp. 943-957.

Fischer, C. 2013. Trust and communication in European agri-food chains. Supply Chain Management: An International Journal 18(2), pp. 208-218.

Flothmann, C., Hoberg, K., Gammelgaard, B. 2018. Disentangling supply chain management competencies and their impact on performance: a knowledge-based view. International Journal of Distribution \& Logistics Management 48(6), pp. 630-655.

Food and Agriculture Organization of the United Nations. 2019. China at a glance. Available at: http://www.fao.org/china/fao-in-china/china-at-a-glance/en/ [Accessed: 12/12/2019].

Foss, N.J., Husted, K., Michailova, S. 2010. Governing knowledge sharing in organizations: level of analysis, governance mechanisms, and research directions. Journal of Management Studies 47(3), pp. 455-482.

Fugate, B.S., Autry, C.W., Davis-Sramek, B., Germain, R.N. 2012. Does knowledge management facilitate logistics-based differentiation? the effect of global manufacturing reach. International Journal of Production Economics 139(2), pp. 496-509.

Goldkuhl, G. 2012. Pragmatism vs interpretivism in qualitative information systems research. European Journal of Information Systems 21(2), pp. 135-146.

Gunasekaran, A., Patel, C., Tirtiroglu, E. 2001. Performance measures and metrics in a supply chain environment. International Journal of Operations and Production Management 21(1), pp. 71-87.

Hammarberg, K., Kirkman, M., Lacey, S. 2016. Qualitative research methods: when to use them and how to judge them. Human Reproduction 31(3), pp. 498-501.

Handfield, R.B.A., Cousins, P.D.B., Lawson, B.C., Petersen, K.J.D. 2015. How can supply management really improve performance? a knowledge-based model of alignment capabilities. Journal of Supply Chain Management 51(3), pp. 3-17.

He, Q., Ghobadian, A., Gallear, D. 2013. Knowledge acquisition in supply chain partnerships: the role of power. International Journal of Production Economics 141(2), pp. 605-618.

Herbert, K., Christoph, T., David B, G., Anders, F. 2015. Supply chain management resources, capabilities and execution. Production Planning and Control 26(7), pp. 525-542.

Hernandez-Espallardo, M., Rodriguez-Orejuela, A., Sanchez-Perez, M. 2010. Interorganisational governance, learning and performance in supply chains. Supply Chain Management: An International Journal 15(2), pp. 101-114.

Hernández, J. E., Mula, J., \& Ferriols, F. J. (2008). A reference model for conceptual modelling of production planning processes. Production Planning and Control, 19(8), 725-734.

Hernández, J. E., Kacprzyk, J., Panetto, H., Fernandez, A., Liu, S., Ortiz, A., \& De-Angelis, M. (2017. Challenges and solutions for enhancing agriculture value chain decision-making. A short review. In Working Conference on Virtual Enterprises (pp. 761-774). Springer, Cham. 
Hernández, J.E. \&, Kacprzyk, J. (2020). Agriculture Value Chain - Challenges and Trends in Academia and Industry, RUC-APS Volume 1, Studies in Systems, Decision and Control, Springer Nature Switzerland. DOI: 10.1007/978-3-030-51047-3.

Howe, K.R. 1988. Against the quantitative-qualitative incompatibility thesis or, dogmas die hard. Educational Researcher 17(1), pp. 10-16.

Huang, C.C, Lin, S.H. 2010. Sharing knowledge in a supply chain using the semantic web. Expert Systems with Applications 37, pp. 3145-3161.

Huang, M-C., Chiu, Y-P., Lu, T-C. 2013. Knowledge governance mechanisms and repatriate's knowledge sharing: the mediating roles of motivation and opportunity. Journal of Knowledge Management 17(5), pp. 677-694.

Iakovou, E., Karagiannidis, A., Vlachos, D., Toka, A. Malamakis, A. 2010. Waste biomass-toenergy supply chain management: a critical synthesis. Waste Management 30, pp. 1860-1870.

Inkpen, A.C., Tsang, E.W.K. 2005. Social capital, networks, and knowledge transfer. Academy of Management Review 30, pp. 146-165.

Jakhar, S.K., Barua, M.K. 2014. An integrated model of supply chain performance evaluation and decision-making using structural equation modelling and fuzzy AHP. Production Planning \& Control 25(11), pp. 938-957.

Jasti, N.V.K., Kodali, R. 2015. A critical review of lean supply chain management frameworks: proposed frameworks. Production Planning \& Control 26(13), pp. 1051-1068.

Jena, J., Sidharth, S., Thakur, L.S., Pathak, D.K., Pandey, V.C. 2017. Total interpretive structural modelling (TISM): approach and application. Journal of Advances in Management Research 14(2), pp. 162-181.

Kanat, S., Atilgan, T. 2014. Effects of knowledge management on supply chain management in the clothing sector: Turkish case. Fibres \& Textiles in Eastern Europe 1(103), pp. 9-13.

Kaplan, R.S., Norton, D.P. 1992. The balanced scorecard - measures that drive performance. Harvard Business Review 70, pp. 71-79.

Kern, T., Willcocks, L. 2000. Exploring information technology outsourcing relationships: theory and practice. Journal of Strategic Information Systems 9(4), pp. 321-350.

Khan, Z.A., Shenkar, O.B., Lew, Y.K.C. 2015. Knowledge transfer from international joint ventures to local suppliers in a developing economy. Journal of International Studies 46(6), pp. 656-675.

Kim, H.A.B., Hur, D.A., Schoenherr, T.C. 2015. When buyer-driven knowledge transfer activities really work: a motivation-opportunity-ability perspective. Journal of Supply Chain Management 51(3), pp. 33-60.

Kim, K.K., Umanath, N.S., Kim, J.Y., Ahrens, F., Kim, B. 2012. Knowledge complementarity and knowledge exchange in supply channel relationships. International Journal of Information Management 32(1), pp. 35-49.

King, N., Horrocks, C. 2010. Interviews in qualitative research. London: Sage Publications. 
Kotsanopoulos, K.V., Arvanitoyannis, I.S. 2017. The role of auditing, food safety, and food quality standards in the food industry: A review. Comprehensive Reviews in Food Science and Food Safety 16, pp. 760-775.

Kumar, N., Brint, A., Shi, E., Upadhyay, A., Ruan, X. 2019. Integrating sustainable supply chain practices with operational performance: an exploratory study of Chinese SMEs. Production Planning \& Control 30(5-6), pp. 464-478.

Kvale, S., Brinkmann, S. 2009. Interviews, 2nd ed. Thousand Oaks, CA: Sage.

Lambert, D.M., Pohlen, T.L. 2001. Supply chain metrics. International Journal of Logistics Management 12(1), pp. 1-19.

Laurie Hughes, D., Dwivedi, Y.K., Rana, N.P., Simintiras, A.C. 2016. Information systems project failure - analysis of causal links using interpretive structural modelling. Production Planning \& Control 27(16), pp. 1313-1333.

Lee, A.H.I., Wang, W-M., Lin, T-Y. 2010. An evolution framework for technology transfer of new equipment in high technology industry. Technological Forecasting \& Social Change 77, pp. 135-150.

Likert, R. 1932. A technique for the measurement of attitudes. In Archives of Psychology No. 140, edited by R.S. Woodworth, 1-55. New York, NY: New York University.

Lim, M.K., Tseng, M-L., Tan, K.H., Bui, T.D. 2017. Knowledge management in sustainable supply chain management: improving performance through an interpretive structural modelling approach. Journal of Cleaner Production 162, pp. 806-816.

Lingegard, S., Lindahl, M. 2015. Integrated product service offerings for rail infrastructurebenefits and challenges regarding knowledge transfer and cultural change in a Swedish case. Journal of Cleaner Production 98, pp. 166-174.

Liu, Y., Huang, Y., Luo, Y., Zhao, Y. 2012. How does justice matter in achieving buyersupplier relationship performance. Journal of Operations Management 30, pp. 355-367.

Lu, Q., Meng, F., Goh, M. 2014. Choice of supply chain governance: self-managing or outsourcing? International Journal of Production Economics 154, pp. 32-38.

Luthra, S., Mangla, S.K., Shankar, R., Garg, C.P., Jakhar, S. 2018. Modelling critical success factors for sustainability initiatives in supply chains in Indian context using Grey-DEMATEL. Production Planning \& Control 29(9), pp. 705-728.

Lyles, M.A., Salk, J.E. 2007. Knowledge acquisition from foreign parents in international joint ventures: an empirical examination in the Hungarian context. Journal of International Business Studies 38, pp. 3-18.

Maestrini, V., Luzzini, D., Maccarrone, P., Caniato, F. 2017. Supply chain performance measurement systems: A systematic review and research agenda. International Journal of Production Economics 183, pp. 299-315.

Mangla, S.K., Luthra, S., Mishra, N., Singh, A., Rana, N.P., Dora, M., Dwivedi, Y. 2018a. Barriers to effective circular supply chain management in a developing country context. Production Planning \& Control 29(6), pp. 551-569. 
Mangla, S.K., Luthra, S., Rich, N., Kumar, D., Rana, N.P., Dwivedi, Y.K. 2018b. Enablers to implement sustainable initiatives in agri-food supply chains. International Journal of Production Economics 23, pp. 379-393.

Marra, M., Ho, W., Edwards, J.S. 2012. Supply chain knowledge management: A literature review. Expert Systems with Applications 39, pp. 6103-6110.

Martinez, V., Pavlov, A., Bourne, M. 2010. Reviewing performance: an analysis of the structure and functions of performance management reviews. Production Planning \& Control 21(1), pp. 70-83.

Mayer, K., Argyres, N. 2004. Learning to contract: evidence from the personal computer industry. Organization Science 15(4), pp. 394-410.

McAdam, R., Humphreys, P., Galbraith, B., Miller, K. 2017. Developing management capability within a horizontal supply chain in performance measurement deployment and evolution: a dynamic capabilities and goal theory perspective. Production Planning \& Control 28(6-8), pp. 610-628.

McArthur, J.B. 1996. From activity-based costing to throughout accounting. Strategic Finance 77(10), pp. 30.

Mentzer, J.T., DeWitt, W., Keebler, J.S., Min, S., Nix, N.W., Smith, C.D., Zacharia, Z.G. 2001. Defining supply chain management. Journal of Business Logistics 22(2), pp. 1-25.

Millar, C.C.J.M., Choi, C.J. 2010. Development and knowledge resources: a conceptual analysis. Journal of Knowledge Management 14(5), pp. 759-776.

Moazzam, M., Garnevska, E., Marr, N.E. 2012. Benchmarking agri-food supply chain networks: A conceptual framework. World Business Capability Congress 2012, 5-7 December 2012. Auckland: New Zealand.

Najmi, A., Makui, A. 2012. A conceptual model for measuring supply chain,s performance. Production Planning \& Control 23(9), pp. 694-706.

Neuman, W.L. 2005. Social research methods, 6th ed. London: Pearson.

Nickerson, J., Zenger, T. 2004. A knowledge-based theory of the firm: the problem-solving perspective. Organizational Science 15(6), pp. 617-632.

Nooteboom, B. 2000. Learning and innovation in organizations and economies. Oxford: Oxford University Press.

North, D.J., Leigh, R., Gough, J. 1983. Monitoring industrial change at the local level: some comments on methods and data sources, in M.J. Healey (ed.) Urban and regional industrial research: the changing UK data base. Norwich: Geo Books, pp. 111-129.

Paton, R.A., McLaughlin, S. 2008. Services innovation: knowledge transfer and the supply chain. European Management Journal 26, pp. 77-83.

Polanyi, M. 1957. The tacit dimension. New York: Anchor Day. 
Puche, J., Ponte, B., Costas, J., Pino, R., de la Fuente, D. 2016. Systemic approach to supply chain management through the visible system model and the theory of constraints. Production Planning \& Control 27(5), pp. 421-430.

Quigley, N.R., Tesluk, P.E., Locke, E.A., Bartol, K.M. 2007. A multilevel investigation of the motivation mechanisms underlying knowledge sharing and performance. Organization Science 18(1), pp. 71-88.

Raisinghani, M.S., Meade, L.L. 2005. Strategic decisions in supply-chain intelligence using knowledge management: an analytic-network-process framework. Supply Chain Management: An International Journal 10, pp. 151-170.

Rajabion, L., Mokhtari, A.S., Khordehbinan, M.W., Zare, M., Hassani, A. 2019. The role of knowledge sharing in supply chain success: literature review, classification and current trends. Journal of Engineering, Design and Technology 17(6), pp. 1222-1249.

Rajendran, R.A., Rajagopal, R.B. 2015. Mitigating risks of knowledge transfer in organisation networks evidence from case studies. International Journal of Knowledge Management Studies 6(3), pp. 279-299.

Roebuck, C. 1996. Constructive feedback: key to higher performance and commitment. Long Range Planning 29(3), pp. 328-336.

Rutten, W., Blaas-Franken, J., Martin, H. 2016. The impact of (low) trust on knowledge sharing. Journal of Knowledge Management 20(2), pp. 199-214.

Saaty, T.L. 1977. A scaling method for priorities in hierarchical structures. Journal of Mathematical Psychology 15, pp. 234-281.

Sammarra, A., Biggiero, L. 2008. Heterogeneity and specificity of inter-firm knowledge flows in innovation networks. Journal of Management Studies 45, pp. 800-829.

Samuel, K.E., Goury, M-L., Gunasekaran, A., Spalanzani, A. 2011. Knowledge management in supply chain: An empirical study From France. Journal of Strategic Information Systems 20, pp. 283-306.

Sangari, M.S., Hosnavi, R., Zahedi, M.R. 2015. The impact of knowledge management processes on supply chain performance: An empirical study. The International Journal of Logistics Management 26(3), pp. 603-626.

Saunders, M., Lewis, P., Thornhill, A. 2019. Research methods for business students, 8th ed. Harlow, England: Pearson Education Limited.

Schepker, D., Oh, Y-W., Martynov, A., Poppo, L. 2014. The many futures of contracts: moving beyond structure and safeguarding to coordination and adaptation. Journal of Management 40(1), pp. 193-225.

Schoenherr, T.A., Griffith, D.A.B., Chandra, A.C. 2014. Knowledge management in supply chains: the role of explicit and tacit knowledge. Journal of Business Logistics 35(2), pp. 121135 .

Sekaran, U., Bougie, R. 2013. Research methods for business, 6th ed. West Sussex: John Wiley \& Sons Ltd. 
Seleem, S.N., Attia, E.A., El-Assal, A. 2016. Managing performance improvement initiatives using DEMATEL method with application case study. Production Planning \& Control 27(78), pp. 637-649.

Shaw, S., Grant, D.B., Mangan, J. 2020. A supply chain practice-based view of enablers, inhibitors and benefits for environmental supply chain performance measurement. Production Planning \& Control, DOI: 10.1080/09537287.2020.1737977.

Simatupang, T.M., Sridharan, R. 2005. An integrative framework for supply chain collaboration. The International Journal of Logistics Management 16(2), pp. 257-274.

Shibin, K.T., Gunasekaran, A., Papadopoulos, T., Dubey, R., Singh, M., Wamba, S.F. 2016. Enablers and barriers of flexible green supply chain management: a total interpretive structural modelling approach. Global Journal of Flexible Systems Management 17(2), pp. 171-188.

Smedlund, A. 2006. The roles of intermediaries in a regional knowledge system. Journal of Intellectual Capital 7(2), pp. 204-220.

Smith Ring, P., Van de Ven, A.H. 1994. Developmental processes of cooperative interorganizational relationships. Academy of Management Review 19(1), pp. 90-118.

Sushil. 2012. Interpreting the interpretive structural model. Global Journal of Flexible Systems Management 13(2), pp. 87-106.

Tatikonda, M.V., Stock, G.N. 2003. Product technology transfer in the upstream supply chain. The Journal of Product Innovation Management 20, pp. 444-467.

Tseng, S.M. 2014. The impact of knowledge management capabilities and supplier relationship management on corporate performance. International Journal of Production Economics 154, pp. 39-47.

Tsolakis, N.K., Keramydas, C.A., Toka, A.K., Aidonis, D.A., Iakovou, E.T. 2014. Agrifood supply chain management: A comprehensive hierarchical decision-making framework and a critical taxonomy. Biosystems Engineering 120, pp. 47-64.

Ukko, J., Saunila, M., Rantala, T. 2020. Connecting relational mechanisms to performance measurement in a digital service supply chain. Production Planning \& Control 31(2-3), pp. 233-244.

UNESCO. 2017. Reading the past, writing the future fifty years of promoting literacy. Paris: UNESCO.

USDA Foreign Agricultural Service. 2017. Chile, exporter guide, excellent opportunities for U.S. exporters of agricultural and related products. Available at: https://apps.fas.usda.gov/newgainapi/api/report/downloadreportbyfilename?filename=Export er\%20Guide_Santiago_Chile_12-28-2017.pdf [Accessed: 16/12/2019].

Vandaele, D., Rangarajan, D., Gemmel, P., Lievens, A. 2007. How to govern business service exchanges: contractual and relational issues. International Journal of Management Reviews 9(3), pp. 237-258.

van Kerkhoff, L. 2014. Knowledge governance for sustainable development: a critical analysis of an emerging concept. Challenges in Sustainability 1(2), pp. 82-93. 
Vis, B. 2012. The comparative advantages of fsQCA and regression analysis for moderately large-N analyses. Sociological Methods \& Research 41(1), pp. 168-198.

Vlachos, I. 2015. Applying lean thinking in the food supply chains: a case study. Production Planning \& Control 26(16), pp. 1351-1367.

Wadhwa, S., Saxena, A. 2005. Knowledge management based supply chain: an evolution perspective. Global Journal of e-Business and Knowledge Management 2(2), pp. 13-29.

Wang, M-C., Chen, P-C., Fang, S-C. 2018. A critical review of knowledge networks and innovation performance: the mediation role of firms' knowledge integration capability. Journal of Business Research 88, pp. 222-233.

Wang, S., Noe, R.A. 2010. Knowledge sharing: a review and directions for future research. Human Resource Management Review 20(2), pp. 115-131.

Wang, X., Li, D., Shi, X. 2012. A fuzzy model for aggregative food safety risk assessment in food supply chains. Production Planning \& Control 23(5), pp. 377-395.

Wellington, J., Szczerbinski, M. 2007. Research methods for the social sciences. London: Continuum.

Yamao, S., de Cieri, H., Hutchings, K. 2009. Transferring subsidiary knowledge to global headquarters: subsidiary senior executives perception of the role of HR configurations in the development of knowledge stocks. Human Resource Management 48(4), pp. 531-554.

Yang, D. 2011. How does knowledge sharing and governance mechanism affect innovation capabilities? - From the coevolution perspective. International Business Research 4(1), pp. 154-157.

Zhang, Q., Zhou, K.Z. 2013. Governing interfirm knowledge transfer in the Chinese market: The interplay of formal and informal mechanisms. Industrial Marketing Management 42, pp. 783-791.

Zhao, G., Liu, S., Lopez, C., Chen, H., Lu, H., Mangla, S.K., Elgueta, S. 2020. Risk analysis of the agri-food supply chain: A multi-method approach. International Journal of Production Research, DOI: 10.1080/00207543.2020.1725684.

Zhao, G., Liu, S., Lopez, C., Lu, H., Elgueta, S., Chen, H., Boshkoska, B.M. 2019. Blockchain technology in agri-food value chain management: A synthesis of applications, challenges and future research directions. Computers in Industry 109, pp. 83-99. 


\section{Appendix A Background of the companies and interviewees}

\begin{tabular}{|c|c|c|c|c|c|}
\hline No & Role in AFSC & Country & $\begin{array}{l}\text { Number } \\
\text { of } \\
\text { employees }\end{array}$ & $\begin{array}{l}\text { Interviewee } \\
\text { s' position }\end{array}$ & $\begin{array}{l}\text { Working } \\
\text { experience }\end{array}$ \\
\hline 1 & Agri-food research institution & \multirow{4}{*}{ Spain } & 45 & $\begin{array}{l}\text { Project } \\
\text { manager }\end{array}$ & 20 years \\
\hline 2 & Cooperative & & 120 & Director & 15 years \\
\hline 3 & Food processor, wholesaler, and distributor & & 80 & Co-owner & 18 years \\
\hline 4 & Retailer & & 30 & Director & 24 years \\
\hline 5 & Seed provider & \multirow{5}{*}{ France } & 18 & $\begin{array}{l}\text { Market } \\
\text { manager }\end{array}$ & 12 years \\
\hline 6 & Agricultural equipment provider & & 24 & $\begin{array}{l}\text { Operation } \\
\text { manager }\end{array}$ & 15 years \\
\hline 7 & Farmers & & 15 & Director & 20 years \\
\hline 8 & Cooperative & & 23 & Director & 18 years \\
\hline 9 & Food processor, wholesaler and distributor & & 60 & Director & 25 years \\
\hline 10 & Agri-food research institution & \multirow{3}{*}{ Italy } & 36 & Director & 10 years \\
\hline 11 & Cooperative & & 48 & $\begin{array}{l}\text { Project } \\
\text { manager }\end{array}$ & 18 years \\
\hline 12 & Food processor & & 32 & $\begin{array}{l}\text { Operation } \\
\text { manager }\end{array}$ & 15 years \\
\hline 13 & Agri-chemical provider & \multirow{10}{*}{ Argentina } & 15 & Co-owner & 20 years \\
\hline 14 & Agri-food research institution & & 60 & Director & 20 years \\
\hline 15 & Government & & 18 & $\begin{array}{l}\text { Middle } \\
\text { management }\end{array}$ & 25 years \\
\hline 16 & Agri-food research institution & & 40 & Director & 12 years \\
\hline 17 & Wholesaler & & 100 & Director & 30 years \\
\hline 18 & Farmers & & 25 & Owner & 30 years \\
\hline 19 & Farmers & & 30 & Owner & 25 years \\
\hline 20 & Farmers & & 40 & Owner & 20 years \\
\hline 21 & Cooperative & & 40 & Director & 15 years \\
\hline 22 & Wholesaler, distributor and retailer & & 70 & Director & 20 years \\
\hline
\end{tabular}


Appendix B Empirical evidence in discovering KGMs

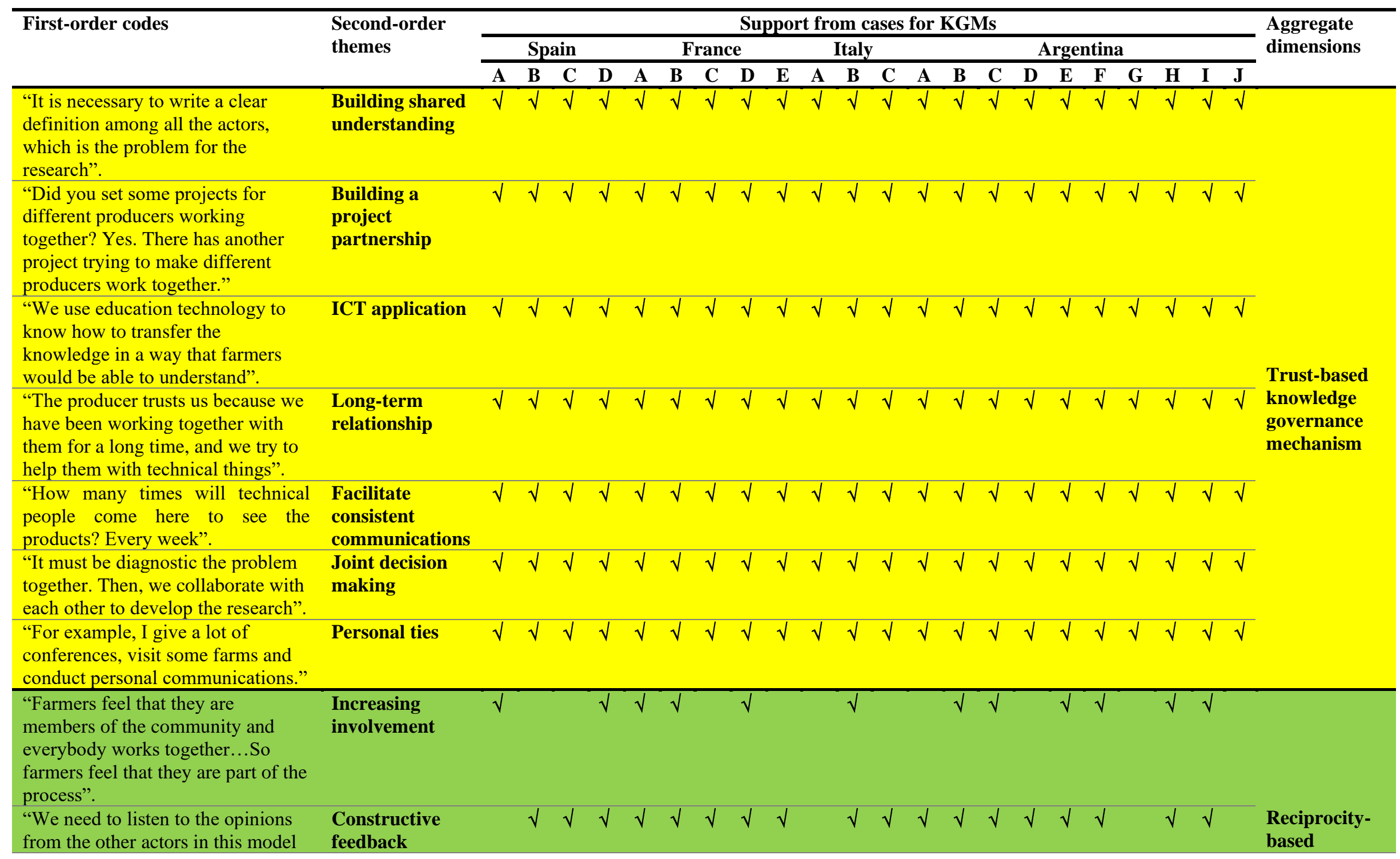


because this would be the

knowledge that you will have to

develop".

"I am insisting on the idea of the

farmers playing an active role in

telling me the research process. It is

not to work against the farmers; it is

to work with the farmers. This is the

different idea".

"We offer quality certification for

\section{Rewards}

farmers if they apply the rules

correctly. These rules include

applying agriculture good practices,

using agri-chemicals correctly and

not using toxic categories".

"There will be new rules to solve

these kinds of problems, for

example, how to collect empty

bottles, where to put empty bottles.

It is important to train farmers, to

transfer knowledge with them.

Thus, they will use better ways to

work."

"Farmers signed a contract with

saying that they will respect the

rules of the auction market."

"If there are fewer middle men, this

means the communication between

producer and consumer is

efficient".

"In this process, it is more about

taking responsibility. According to

the knowledge experience, we take

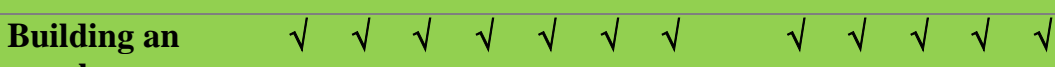

equal

relationship

$\begin{array}{llllllllllllllllllllll}\sqrt{ } & \sqrt{ } & \sqrt{ } & \sqrt{ } & \sqrt{ } & \sqrt{ } & \sqrt{ } & \sqrt{ } & \sqrt{ } & \sqrt{ } & \sqrt{ } & \sqrt{ } & \sqrt{ } & \sqrt{ } & \sqrt{ } & \sqrt{ } & \sqrt{ } & \sqrt{ } & \sqrt{ } & \sqrt{ } & \sqrt{ } & \sqrt{ }\end{array}$

knowledge

governance

mechanism

different responsibility..."

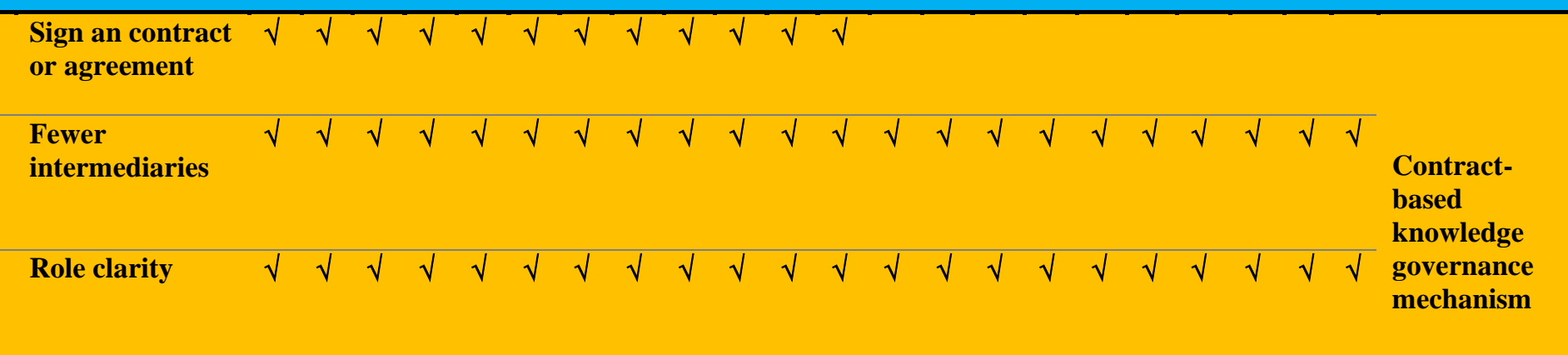

Legislations and rules

application

Market-based

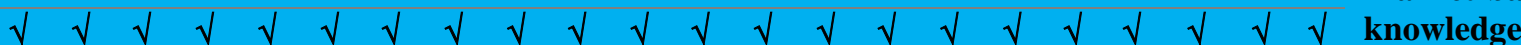

governance

mechanism

based

governance
mechanism 
Appendix C Empirical evidence in discovering AFSC performance indicators

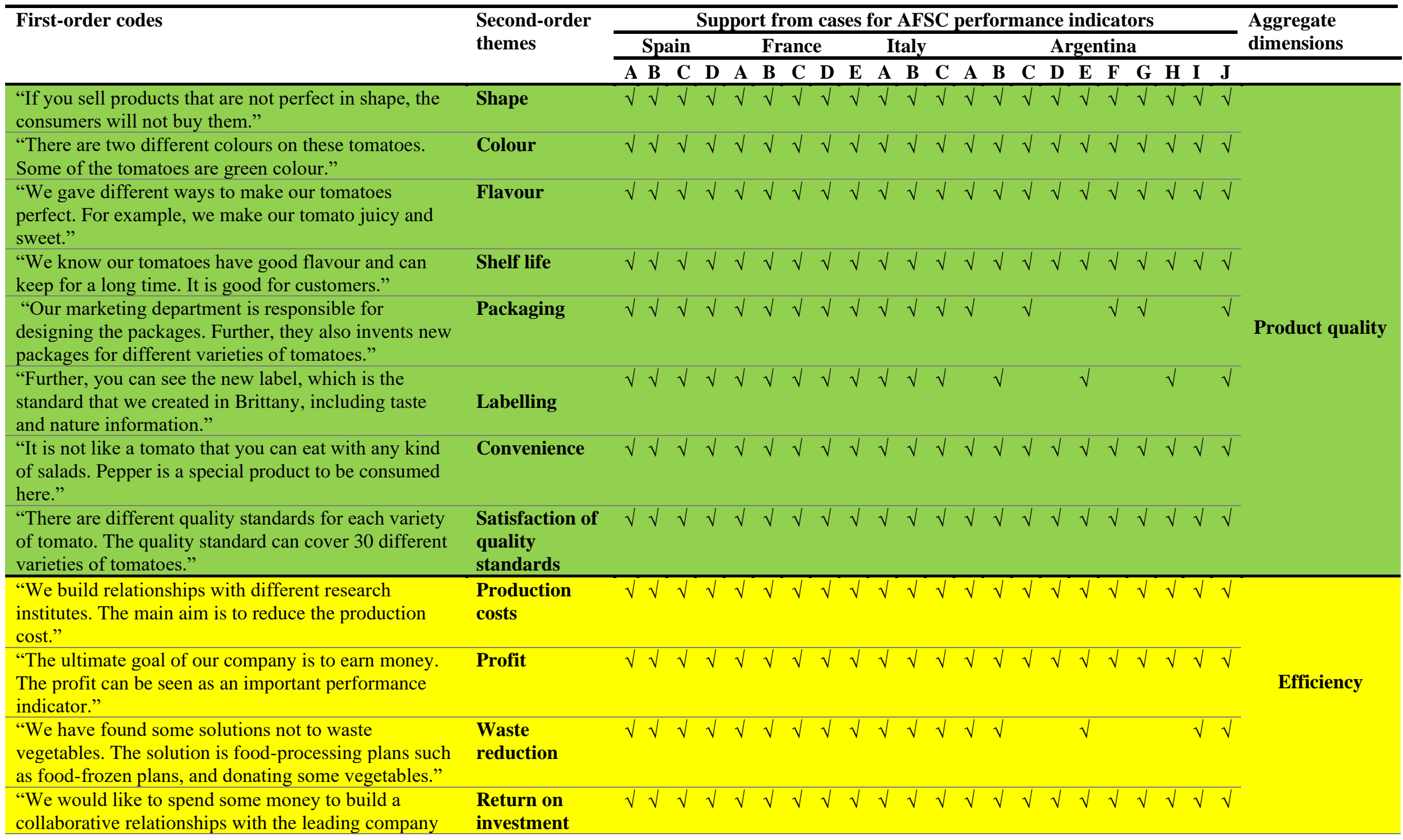


in this field. This kind of investment would help us to earn money in the near future."

"From August to September in Brittany, we stocked lettuce and sold them to the fresh food market before

the buyer came here."

"We continuously update our products to improve their quality, flavour, shape, and shelf life to satisfy

our customer requirements."

"The minimum is the six varieties of tomatoes in one box. For this type of tomato, 40 tomatoes are packed in one box."

"We build long-term relationships with distributors to acquire delivery flexibility."

"We need to change products according to the seasons."

"The traceability technology that we use to let people know where the station is, the producers' number, the green house number, and pick-up number.'

"The Buenos Aires province is strong enough to control agri-chemical contamination on vegetables."

"Some supermarkets will not buy such red tomatoes

for logistical reasons."

"There are families that live with the amount of garbage

very near the houses, and then they have drugs and

water pollution. They may not have a toilet or they have one very near the houses for ten persons' use.'

"It is quite a high electricity cost -3000 dollars per month in summer time."

"We get water from the underground, so it is free."

"We have made some improvements. For example, farmers are worried about the quality of the water (the importance of the quality of the water)."

"...We know the quality of this variety of tomato is not good enough because of customer complaints.

Thus, most of the farmers decided to set a more strict

quality standard next year."

"We always deliver products in three days across the whole country.

$\begin{array}{lllllllllllllllllllllll}\text { Inventory } & \sqrt{ } & \sqrt{ } & \sqrt{ } & \sqrt{ } & \sqrt{ } & \sqrt{ } & \sqrt{ } & \sqrt{ } & \sqrt{ } & \sqrt{ } & \sqrt{ } & \sqrt{ } & \sqrt{ } & \sqrt{ } & \sqrt{ } & \sqrt{ } & \sqrt{ } & \sqrt{ } & \sqrt{ } & \sqrt{ } & \sqrt{ } & \sqrt{ }\end{array}$

$\begin{array}{llllllllllllllllllllllll}\text { Customer } & \sqrt{ } & \sqrt{ } & \sqrt{ } & \sqrt{ } & \sqrt{ } & \sqrt{ } & \sqrt{ } & \sqrt{ } & \sqrt{ } & \sqrt{ } & \sqrt{ } & \sqrt{ } & \sqrt{ } & \sqrt{ } & \sqrt{ } & \sqrt{ } & \sqrt{ } & \sqrt{ } & \sqrt{ } & \sqrt{ } & \sqrt{ } & \sqrt{ }\end{array}$

satisfaction

Volume

flexibility

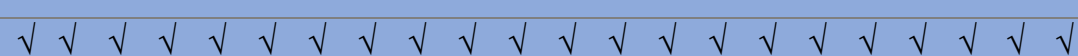

Delivery

flexibility

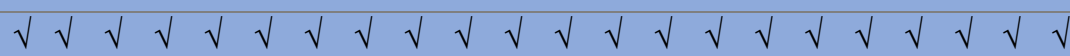

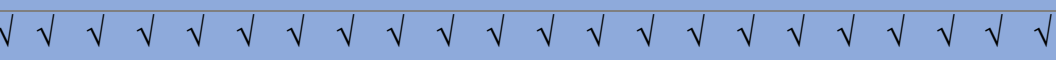

flexibility

Traceability

$\begin{array}{llllllllllllllllllllll} & \sqrt{ } & \sqrt{ } & \sqrt{ } & \sqrt{ } & \sqrt{ } & \sqrt{ } & \sqrt{ } & \sqrt{ } & \sqrt{ } & \sqrt{ } & \sqrt{ } & \sqrt{ } & \sqrt{ } & \sqrt{ } & \sqrt{ } & \sqrt{ } & & \sqrt{ } & \sqrt{ } & \sqrt{ }\end{array}$

Pesticide use

Storage and

transportation

Working

condition

$\begin{array}{lllllllllllllllllllllll}\text { Energy use } & \sqrt{ } & \sqrt{ } & \sqrt{ } & \sqrt{ } & \sqrt{ } & \sqrt{ } & \sqrt{ } & \sqrt{ } & \sqrt{ } & \sqrt{ } & \sqrt{ } & \sqrt{ } & \sqrt{ } & \sqrt{ } & \sqrt{ } & \sqrt{ } & \sqrt{ } & \sqrt{ } & \sqrt{ } & \sqrt{ } & \sqrt{ } & \sqrt{ }\end{array}$

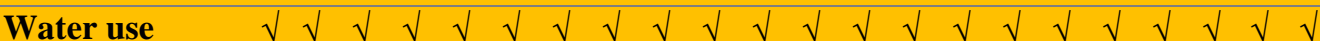

Water quality

Customer

complaints

Lead time
Process quality

Responsiveness

Flexibility

Responsiveness


Appendix D Level partitioning of reachability matrix

\begin{tabular}{|c|c|c|c|c|}
\hline Elements & Reachability set & Antecedent set & Intersection & Level \\
\hline \multicolumn{5}{|l|}{ Iteration 1} \\
\hline E1 & $1,2,4,5,6,7,8,9$ & $1,2,3,4$ & $1,2,4$ & \\
\hline E2 & $1,2,4,5,6,7,8,9$ & $1,2,3,4$ & $1,2,4$ & \\
\hline E3 & $1,2,3,4,5,6,7,8,9$ & 3 & 3 & \\
\hline E4 & $1,2,4,5,6,7,8,9$ & $1,2,3,4$ & $1,2,4$ & \\
\hline E5 & 5,9 & $1,2,3,4,5,6,7$ & 5 & \\
\hline E6 & $5,6,8,9$ & $1,2,3,4,6,7$ & 6 & \\
\hline E7 & $5,6,7,8,9$ & $1,2,3,4,7$ & 7 & \\
\hline E8 & 8,9 & $1,2,3,4,6,7,8$ & 8 & \\
\hline E9 & 9 & $1,2,3,4,5,6,7,8,9$ & 9 & Level I \\
\hline \multicolumn{5}{|l|}{ Iteration 2} \\
\hline E1 & $1,2,4,5,6,7,8$ & $1,2,3,4$ & $1,2,4$ & \\
\hline E2 & $1,2,4,5,6,7,8$ & $1,2,3,4$ & $1,2,4$ & \\
\hline E3 & $1,2,3,4,5,6,7,8$ & 3 & 3 & \\
\hline E4 & $1,2,4,5,6,7,8$ & $1,2,3,4$ & $1,2,4$ & \\
\hline E5 & 5 & $1,2,3,4,5,6,7$ & 5 & Level II \\
\hline E6 & $5,6,8$ & $1,2,3,4,6,7$ & 6 & \\
\hline E7 & $5,6,7,8$ & $1,2,3,4,7$ & 7 & \\
\hline E8 & 8 & $1,2,3,4,6,7,8$ & 8 & Level II \\
\hline \multicolumn{5}{|l|}{ Iteration 3} \\
\hline E1 & $1,2,4,6,7$ & $1,2,3,4$ & $1,2,4$ & \\
\hline E2 & $1,2,4,6,7$ & $1,2,3,4$ & $1,2,4$ & \\
\hline E3 & $1,2,3,4,6,7$ & 3 & 3 & \\
\hline E4 & $1,2,4,6,7$ & $1,2,3,4$ & $1,2,4$ & \\
\hline E6 & 6 & $1,2,3,4,6,7$ & 6 & Level III \\
\hline E7 & 6,7 & $1,2,3,4,7$ & 7 & \\
\hline \multicolumn{5}{|l|}{ Iteration 4} \\
\hline E1 & $1,2,4,7$ & $1,2,3,4$ & $1,2,4$ & \\
\hline E2 & $1,2,4,7$ & $1,2,3,4$ & $1,2,4$ & \\
\hline E3 & $1,2,3,4,7$ & 3 & 3 & \\
\hline E4 & $1,2,4,7$ & $1,2,3,4$ & $1,2,4$ & \\
\hline E7 & 7 & $1,2,3,4,7$ & 7 & Level IV \\
\hline \multicolumn{5}{|l|}{ Iteration 5} \\
\hline E1 & $1,2,4$ & $1,2,3,4$ & $1,2,4$ & Level V \\
\hline E2 & $1,2,4$ & $1,2,3,4$ & $1,2,4$ & Level V \\
\hline E3 & $1,2,3,4$ & 3 & 3 & \\
\hline E4 & $1,2,4$ & $1,2,3,4$ & $1,2,4$ & Level V \\
\hline \multicolumn{5}{|l|}{ Iteration 6} \\
\hline E3 & 3 & 3 & 3 & Level VI \\
\hline
\end{tabular}




\section{Appendix E Questionnaire about knowledge governance mechanisms in improving AFSC performance}

Part A. Evaluate knowledge governance mechanisms (KGMs)

1. To what extent do you think the following elements of KGMs are appropriate or not? Please tick $(\sqrt{ })$ in the following table.

\begin{tabular}{|c|c|c|c|c|c|c|}
\hline \multirow[t]{2}{*}{ KGMs } & \multirow[t]{2}{*}{ Elements } & \multicolumn{5}{|c|}{ Descriptor } \\
\hline & & $\begin{array}{c}\text { Strongly } \\
\text { agree }\end{array}$ & Agree & Neutral & Disagree & $\begin{array}{l}\text { Strongly } \\
\text { disagree }\end{array}$ \\
\hline \multirow{7}{*}{$\begin{array}{l}\text { Trust-based } \\
\text { KGM }\end{array}$} & Building shared understanding & & & & & \\
\hline & Building project partnership & & & & & \\
\hline & ICT application & & & & & \\
\hline & Long-term relationship & & & & & \\
\hline & Facilitate consistent communication & & & & & \\
\hline & Joint decision-making & & & & & \\
\hline & Personal ties & & & & & \\
\hline \multicolumn{7}{|l|}{$\begin{array}{l}\text { Any other } \\
\text { elements? }\end{array}$} \\
\hline \multirow{2}{*}{$\begin{array}{l}\text { Market- } \\
\text { based KGM }\end{array}$} & Rewards & & & & & \\
\hline & Legislations and rules application & & & & & \\
\hline \multicolumn{7}{|l|}{$\begin{array}{l}\text { Any other } \\
\text { elements? }\end{array}$} \\
\hline \multirow{3}{*}{$\begin{array}{l}\text { Reciprocity- } \\
\text { based KGM }\end{array}$} & Increasing involvement & & & & & \\
\hline & Constructive feedback & & & & & \\
\hline & Building equal relationship & & & & & \\
\hline \multicolumn{7}{|l|}{$\begin{array}{l}\text { Any other } \\
\text { elements? }\end{array}$} \\
\hline \multirow{3}{*}{$\begin{array}{l}\text { Contract- } \\
\text { based KGM }\end{array}$} & Sign an contract or agreement & & & & & \\
\hline & Fewer intermediates & & & & & \\
\hline & Role clarity & & & & & \\
\hline $\begin{array}{l}\text { Any other } \\
\text { elements? }\end{array}$ & & & & & & \\
\hline
\end{tabular}

2. If you disagree or strongly disagree the any of the above elements used for building different KGMs, please tell me why. 
Part B. Evaluate performance indicators for AFSC

1. To what extent do you think the following performance indicators used for AFSC of Chile are appropriate or not? Please tick $(\sqrt{ })$ in the following table.

\begin{tabular}{|c|c|c|c|c|c|c|}
\hline \multirow{2}{*}{$\begin{array}{l}\text { AFSC performance } \\
\text { categories }\end{array}$} & \multirow{2}{*}{$\begin{array}{l}\text { Performance } \\
\text { indictors }\end{array}$} & \multicolumn{5}{|c|}{ Descriptor } \\
\hline & & $\begin{array}{c}\text { Strongly } \\
\text { agree }\end{array}$ & Agree & Neutral & Disagree & $\begin{array}{l}\text { Strongly } \\
\text { disagree }\end{array}$ \\
\hline \multirow{8}{*}{ Product quality } & Shape & & & & & \\
\hline & Colour & & & & & \\
\hline & Flavour & & & & & \\
\hline & Shelf life & & & & & \\
\hline & Packaging & & & & & \\
\hline & Labelling & & & & & \\
\hline & Convenience & & & & & \\
\hline & Quality standards & & & & & \\
\hline \multicolumn{7}{|l|}{$\begin{array}{l}\text { Any other performance } \\
\text { indicators? }\end{array}$} \\
\hline \multirow{7}{*}{ Process quality } & Traceability & & & & & \\
\hline & Pesticide use & & & & & \\
\hline & $\begin{array}{l}\text { Storage and } \\
\text { transportation }\end{array}$ & & & & & \\
\hline & $\begin{array}{l}\text { Working } \\
\text { condition }\end{array}$ & & & & & \\
\hline & Energy use & & & & & \\
\hline & Water use & & & & & \\
\hline & Water quality & & & & & \\
\hline \multicolumn{7}{|l|}{$\begin{array}{l}\text { Any other performance } \\
\text { indicators? }\end{array}$} \\
\hline \multirow{5}{*}{ Efficiency } & Production costs & & & & & \\
\hline & Profit & & & & & \\
\hline & Waste reduction & & & & & \\
\hline & $\begin{array}{l}\text { Return on } \\
\text { investment }\end{array}$ & & & & & \\
\hline & Inventory & & & & & \\
\hline \multicolumn{7}{|l|}{$\begin{array}{l}\text { Any other performance } \\
\text { indicators? }\end{array}$} \\
\hline \multirow{4}{*}{ Flexibility } & $\begin{array}{l}\text { Customer } \\
\text { satisfaction }\end{array}$ & & & & & \\
\hline & Volume flexibility & & & & & \\
\hline & $\begin{array}{l}\text { Delivery } \\
\text { flexibility }\end{array}$ & & & & & \\
\hline & Product flexibility & & & & & \\
\hline \multicolumn{7}{|l|}{$\begin{array}{l}\text { Any other performance } \\
\text { indicators? }\end{array}$} \\
\hline \multirow[t]{2}{*}{ Responsiveness } & $\begin{array}{l}\text { Customer } \\
\text { complaints }\end{array}$ & & & & & \\
\hline & Lead time & & & & & \\
\hline $\begin{array}{l}\text { Any other performance } \\
\text { indicators? }\end{array}$ & & & & & & \\
\hline
\end{tabular}

2. If you disagree or strongly disagree with any of the above performance indicators used for AFSC of Chile, please tell me why. 
Part C. Evaluate KGMs in improving AFSC performance

1. To what extent do you think the KGMs improve AFSC performance? Please fill in 1 5 in this form ( 5 represents strongest, whereas 1 represents weakest).

\begin{tabular}{llllll}
\hline KGMs in & improving & \multicolumn{3}{c}{ AFSC performance categories } \\
\cline { 2 - 5 } AFSC performance & $\begin{array}{l}\text { Product } \\
\text { quality }\end{array}$ & $\begin{array}{l}\text { Process } \\
\text { quality }\end{array}$ & Efficiency & Flexibility & Responsiveness \\
\hline \multirow{3}{*}{ KGMs } & $\begin{array}{l}\text { Trust- } \\
\text { based }\end{array}$ & & & \\
\cline { 2 - 5 } & $\begin{array}{l}\text { Market- } \\
\text { based }\end{array}$ & & & \\
\cline { 2 - 5 } & $\begin{array}{l}\text { Reciprocity- } \\
\text { based }\end{array}$ & & \\
& $\begin{array}{l}\text { Norm- } \\
\text { based }\end{array}$ & & \\
\hline
\end{tabular}

2. If you fill the form in with 5, please indicate the reason why do you think KGMs can help to increase AFSC performance effectively. If you fill the form in with 1, please indicate why do you think KGM cannot effectively increase the performance of AFSC. 